\title{
A eukaryotic-type signalling system of Pseudomonas aeruginosa contributes to oxidative stress resistance, intracellular survival and virulence
}

\author{
Jana Goldová ${ }^{1}$, Aleš Ulrych ${ }^{1}$, Kamil Hercík ${ }^{1,2}$ and Pavel Branny ${ }^{1 *}$
}

\begin{abstract}
Background: The genome of Pseudomonas aeruginosa contains at least three genes encoding eukaryotic-type Ser/ Thr protein kinases, one of which, $p p k A$, has been implicated in $P$. aeruginosa virulence. Together with the adjacent pppA phosphatase gene, they belong to the type VI secretion system (H1-T6SS) locus, which is important for bacterial pathogenesis. To determine the biological function of this protein pair, we prepared a pppA-ppkA double mutant and characterised its phenotype and transcriptomic profiles.

Results: Phenotypic studies revealed that the mutant grew slower than the wild-type strain in minimal media and exhibited reduced secretion of pyoverdine. In addition, the mutant had altered sensitivity to oxidative and hyperosmotic stress conditions. Consequently, mutant cells had an impaired ability to survive in murine macrophages and an attenuated virulence in the plant model of infection. Whole-genome transcriptome analysis revealed that pppA-ppkA deletion affects the expression of oxidative stress-responsive genes, stationary phase $\sigma$ factor RpoS-regulated genes, and quorum-sensing regulons. The transcriptome of the pppA-ppkA mutant was also analysed under conditions of oxidative stress and showed an impaired response to the stress, manifested by a weaker induction of stress adaptation genes as well as the genes of the SOS regulon. In addition, expression of either Rpos-regulated genes or quorum-sensing-dependent genes was also affected. Complementation analysis confirmed that the transcription levels of the differentially expressed genes were specifically restored when the pppA and ppkA genes were expressed ectopically.

Conclusions: Our results suggest that in addition to its crucial role in controlling the activity of $P$. aeruginosa H1T6SS at the post-translational level, the PppA-PpkA pair also affects the transcription of stress-responsive genes. Based on these data, it is likely that the reduced virulence of the mutant strain results from an impaired ability to survive in the host due to the limited response to stress conditions.
\end{abstract}

\section{Background}

Pseudomonas aeruginosa is a gram-negative, opportunistic pathogen that causes serious acute and chronic infections and presents considerable complications for burned patients, patients with cystic fibrosis, and those in other immunocompromised states [1]. The production of a wide variety of virulence factors that enhance

\footnotetext{
* Correspondence: branny@biomed.cas.cz

${ }^{1}$ Cell and Molecular Microbiology Division, Institute of Microbiology of the ASCR, v.vi.i, Academy of Sciences of the Czech Republic, Vídeňská 1083, 142 20 Prague 4, Czech Republic

Full list of author information is available at the end of the article
}

the survival of the bacterium within the host is regulated via density-dependent quorum sensing and by the growth phase-dependent RpoS system [2]. Moreover, $P$. aeruginosa has an intrinsic ability to resist a variety of antimicrobial agents. This ability is further strengthened within the infected host by the formation of highly antibiotic-resistant biofilms $[3,4]$. These features make the treatment of $P$. aeruginosa infections very difficult and, therefore, the identification of new therapeutic targets has become very important.

Protein phosphorylation is considered the universal language for inter- and intra-cellular communication in

\section{Biomed Central}


all living organisms. This process, catalysed by protein kinases, enables the translation of extracellular signals into cellular responses and also allows for adaptation to a constantly changing environment. In recent years, a number of bacterial eukaryotic-type Ser/Thr protein kinases (STPKs) and phosphoprotein phosphatases have been identified. These enzymes operate in many bacteria, in which they constitute a signalling network that is independent of the canonical two-component system circuits.

Prokaryotic STPKs regulate various cellular functions, such as developmental processes [5,6], primary and secondary metabolism $[7,8]$, stress responses [9], and biofilm formation [10].

STPKs also play a role in the virulence of many bacterial pathogens such as streptococci, Staphylococcus aureus [11], Mycobacterium tuberculosis [12], Yersinia spp. [13,14], and P. aeruginosa [15-17].

It has been observed that the protein kinase PpkA of $P$. aeruginosa characterized by Wang et al. [17] and Motley and Lory [18] is specifically and highly induced during the infection of neutropenic mice and, therefore, it has been implicated in $P$. aeruginosa virulence [17]. The $p p k A$ gene has also been identified as a component of the HSI-I genetic locus that encodes a novel secretion system (H1-T6SS), designated as the type VI secretion system (T6SS), which functions in bacterial pathogenesis [19]. It has been shown that the secretion of Hcp1 protein, VgrG proteins and Tse1-3 proteins is post-translationally regulated by PpkA [15]. Hcp1 interacts with VgrG proteins VgrG1 and VgrG4 [15,20]. The function of the Hcp/Vgr complex remains unclear; however, it is believed that the proteins are extracellular structural components of the secretion apparatus [15,21]. Third group of proteins secreted by H1-T6SS is represented by Tse1-3, where Tse 2 is the toxin component of toxinimmunity system and is specifically targeted to bacteria [15]. Phosphorylation of the Fha1 protein containing the forkhead-associated (FHA) domain by PpkA leads to the recruitment of T6SS components to the inner membrane, which results in the secretion of periplasmic Hcp1 and other proteins across the outer membrane. In addition, PpkA activity is antagonised by its cognate phosphatase, PppA, which exhibits phosphatase activity on phosphorylated Fha1. Protein TagR, whose gene is downstream of $p p p A-p p k A$, is required for PpkA activation [21].

In the present study, we have carried out phenotypic investigations of a $p p p A-p p k A$ double mutant. The $p p p A-p p k A$ null mutant showed decreased resistance to $\mathrm{H}_{2} \mathrm{O}_{2}$-induced oxidative stress and increased sensitivity to macrophage-mediated killing. In addition, mutations in these genes led to a lower sensitivity to osmotic stress. These results suggest that the expression of the
PppA-PpkA regulatory pair can contribute to $P$. aeruginosa resistance to diverse environmental cues. Furthermore, we show that the $p p p A-p p k A$ mutation affects $P$. aeruginosa virulence in the lettuce leaf model of infection.

Microarray analysis was used to analyse the transcriptomes of the mutant and wild-type strains under standard and oxidative stress conditions. This analysis revealed that the $p p p A-p p k A$ mutation is pleiotropic. Several functional gene categories have been identified that could account for a reduced stress response and bacterial fitness. In addition to the oxidative stressresponsive genes, PppA-PpkA affects the expression of genes regulated by stationary phase $\sigma$-factor RpoS as well as the las and rhl quorum sensing regulons. When exposed to hydrogen peroxide stress, the $p p p A-p p k A$ mutant exhibited an impaired response of the stressinduced genes and altered expression of genes of the quorum sensing (QS)-regulated PA2134-2192 locus and Pho regulon genes.

Collectively, the results led us to speculate that the PppA-PpkA pair can sense external stress signals and regulate the response of $P$. aeruginosa to environmental conditions through its possible connection with RpoS/ QS regulons.

\section{Methods}

\section{Bacterial strains, plasmids, and growth conditions}

The bacterial strains and plasmids used in this study are listed in Table 1. Escherichia coli JM109 was grown in Luria-Bertani (LB) medium at $37^{\circ} \mathrm{C}$. $P$. aeruginosa PAO1 was grown in LB medium or minimal M9 medium if not otherwise stated. M9 medium contained $2 \%$ glucose as a carbon source in all cases. Only for growth characteristics comparison glycerol (2\%), instead of glucose as a carbon source, was used. Elastin broth plates [22] and calcium caseinate agar [23] were used to determine elastase activity. SW blue plates [24] were used for rhamnolipid production. Haemolytic activity was determined on blood agar. Antibiotics were added when necessary at the following concentrations (in $\mu \mathrm{g} \bullet \mathrm{ml}^{-1}$ ): ampicillin (Ap), 100; gentamicin (Gm), 15 (for E. coli); carbenicillin (Cb), 250; gentamicin, 100 (for P. aeruginosa).

\section{Construction of the $P$. aeruginosa $\triangle p p p A-p p k A$ mutant}

The deletion was achieved by crossover PCR mutagenesis [25] and an improved method for gene replacement in $P$. aeruginosa [26]. Crossover PCR was used to generate a fragment that linked 800-bp and 1,035-bp fragments corresponding to downstream and upstream flanking regions of the $p p p A-p p k A$ loci, respectively. Oligonucleotides used in this study are listed in Additional file 1 . The final construct was prepared by the directional cloning of fragments into a suicide vector, 
Table 1 Bacterial strains and plasmids used in this study

\begin{tabular}{|c|c|c|}
\hline Strain/plasmid & Genotype or description $^{a}$ & Source \\
\hline \multicolumn{3}{|l|}{ Strains } \\
\hline \multicolumn{3}{|l|}{ P. aeruginosa } \\
\hline PAO1 & wild type & T. Köhler \\
\hline$\triangle p p p A-p p k A$ & PAO1 with unmarked deletion of $p p p A-p p k A$ & This work \\
\hline PAO1::tn7TLAC & PAO1::mini-tn7T-LAC & This work \\
\hline$\triangle \because: \operatorname{tn} 7 T L A C$ & $\triangle p p p A-p p k A::$ mini-tn7T-LAC & This work \\
\hline$\triangle \because: \operatorname{tn} 7 T L A C p a k$ & $\triangle p p p A-p p k A::$ mini-tn7T-LAC-pppA-ppkA & This work \\
\hline \multicolumn{3}{|l|}{ E. coli } \\
\hline XL1-blue & recA1 endA1 gyrA96 thi hsdR17 $\left(\mathrm{r}_{\mathrm{k}}^{-}, \mathrm{m}_{\mathrm{k}}^{+}{ }^{+}\right)$supE44 relA1 lac $\left[\mathrm{F}^{\prime}\right.$ proAB ${ }^{+}$lacla $\Delta($ lacZ)M15::Tn10] & Stratagene \\
\hline JM109 & endA1 recA1 gyrA96 thi hsdR17 (rk-mk+) supE44 $\triangle($ lac-proAB), [F' traD36 proAB lacla $\Delta($ lacZ)M15] & Promega \\
\hline \multicolumn{3}{|l|}{ Plasmids } \\
\hline pEX18Ap & $\mathrm{Ap}^{\mathrm{R}}$, ori $\mathrm{T}^{+} \mathrm{sacB}^{+}$, gene repacement vector with MSC from pUC18 & $(24)$ \\
\hline pPS858 & $A p^{R}, G^{R}, g f p^{+}$, contains $G m^{R}-G F P$ FRT cassette & $(24)$ \\
\hline pFLP2 & $A p^{R}$, contains FLP recombinase gene & $(24)$ \\
\hline pUC18-mini-Tn7T-LAC & $A p^{R}, G m^{R}$, mini-Tn7T-Gm Gateway-compatible cloning and delivery vector with lacl ${ }^{q}$-Ptac expression cassette & (7) \\
\hline pTNS2 & Helper plasmid for integration of the expression casette & (7) \\
\hline pUC18miniTn7TLACpak & pUC18-mini-Tn7T-LAC expressing pppA-ppkA & This work \\
\hline
\end{tabular}

pEX18Ap, and the subsequent cloning of the $\mathrm{Gm}^{\mathrm{R}}$-GFP FRT cassette from pPS858 into a BamHI site. The resulting plasmid was then electroporated into wild-type $P$. aeruginosa cells. The $\mathrm{Gm}^{\mathrm{R}}$ marker was removed by Flp-mediated excision following previously described methods [26]. The mutant obtained was verified by both PCR and Southern blot analysis.

\section{Complementation}

For complementation analysis, recombinant plasmids were transformed into the $P$. aeruginosa PAO1 and mutant strains by electroporation. Single-copy complementation was achieved by cloning the DNA fragment into pUC18-mini-Tn7T-LAC, a mini-Tn7 vector containing a tac promoter, followed by integration into the single att $\operatorname{Tn} 7$ site on the $P$. aeruginosa chromosome [27]. Specifically, a 4,116-bp SacI-KpnI DNA fragment containing the $p p p A-p p k A$ genes was amplified by PCR using the PPPAinfpUCF-PPKAinfpUCR oligonucleotide pair. The PCR fragment was subcloned into pUC18mini-Tn7T-LAC to yield pUC18miniTn7TLACpak, in which the $p p p A-p p k A$ genes are expressed from the tac promoter. The mini-Tn7T-LACpak segment contained on this plasmid was transposed into the chromosome of the $\triangle p p p A-p p k A$ strain by coelectroporation with pTNS2. Insertion events were verified by PCR, and the $\mathrm{Gm}^{\mathrm{R}}$ marker was removed by Flp-mediated excision following previously described methods [26]. Control PAO1 and $\triangle p p p A-p p k A$ strains contained miniTn7TLAC integrated into the chromosome. The strains obtained were verified by both PCR and Southern blot analysis.

\section{Motility assays}

Swarming motility was determined as described by Kohler et al. [24]. All strains were inoculated by toothpick with individual colonies from a fresh LB agar plates. Incubation was done at $37^{\circ} \mathrm{C}$ for 24 hours. Swimming motility was determined as described by Whitchurch et al. [28]. Cells were stab-inoculated into a LB plate with $0.3 \%$ agar. The motility was examined by monitoring the circular turbid zone formed by the bacterial cells migrating away from the point of inoculation. Twitching motility was determined as described by Schweizer and Choi [29]. All strains were stab-inoculated through a LB plate containing $1 \%$ agar and grown 72 hour at $37^{\circ} \mathrm{C}$. The agar was carefully removed, and residue adhering to the Petri dish was stained with Coomassie brilliant blue R250 (0.05\% in 40\% methanol, $10 \%$ acetic acid).

\section{Quantification of pigments and elastase assay}

Overnight LB cultures were diluted in fresh LB medium and were grown for 24,48 , and $72 \mathrm{~h}$ at $37^{\circ} \mathrm{C}$. For extraction of pyocyanin, a $5 \mathrm{ml}$ sample of the supernatant was mixed with $5 \mathrm{ml}$ chloroform and the lower organic layer was separated. To this layer, $1.5 \mathrm{ml} 0.2 \mathrm{M}$ $\mathrm{HCl}$ was added and pyocyanin-rich aqueous phase was separated. The amount of pyocyanin within the extracted layer was determined by measuring the $\mathrm{OD}_{520}$ [30] and normalized to the respective cell densities $\left(\mathrm{OD}_{600}\right)$.

Elastase activity was determined in these same cultures from $100 \mu \mathrm{l}$ of supernatants using Elastin-Congo Red (Sigma) and spectrophotometric measurement at $495 \mathrm{~nm}$ as previously described by Rust et al. [31]. 
Pyoverdine concentrations were calculated from supernatant of cultures grown 24 hours in Casamino Acids medium (CAA) by spectrophotometric measurement at $405 \mathrm{~nm}$ [32]. Amount of pyoverdine was normalized to the respective cell densities $\left(\mathrm{OD}_{600}\right)$.

\section{Quantification of alginate}

Selected strains were grown on LB agar (three plates per strain) at $37^{\circ} \mathrm{C}$ for 48 hours. Cells were washed from plates and resuspended in $0.9 \% \mathrm{NaCl}$. Alginate isolation and purification were performed as described by May and Chakrabarty [33]. Amount of alginate was normalized to the respective bacterial dry weight.

\section{Antibiotic resistance test}

For general tests with chloramphenicol, carbenicillin, pefloxacin, tetracycline and trimethoprim, we used gradient antibiotic plates [34]. Minimal inhibitory concentrations (MICs) for chloramphenicol and carbenicillin were determined by population analysis profiling [35]. Briefly, serial dilutions of early stationary phase cultures were plated on LB agar plates containing different concentrations of chloramphenicol or carbenicillin. The plates were incubated at $37^{\circ} \mathrm{C}$ for $24 \mathrm{~h}$, and the number of bacteria capable of forming colonies in the presence of various antibiotic concentrations was counted.

\section{Macrophage-mediated bactericidal assay}

Macrophage-mediated bactericidal assays were carried out as described previously [36] with slight modification. The immortalised murine macrophage cell line J774.2 was used to examine the rate of survival in vitro. Macrophages were grown in Dulbecco's modified Eagle's medium (low glucose) supplemented with $5 \mathrm{mM}$ glutamine and $5 \%$ fetal bovine serum (Sigma) in a $5 \% \mathrm{CO}_{2}$ atmosphere at $37^{\circ} \mathrm{C}$. Mid-log-phase $P$. aeruginosa grown in $\mathrm{LB}$ broth at $37^{\circ} \mathrm{C}$ was collected by centrifugation at $5,000 \mathrm{~g}$ and resuspended to an $\mathrm{OD}_{600}$ of 0.4 in PBS. Macrophages $\left(5 \times 10^{7}\right)$ were incubated in Dulbecco's modified Eagle's medium-5\% fetal bovine serum with the wild-type and mutant strain of $P$. aeruginosa $(5 \times$ $10^{7} \mathrm{CFU}$ ) for $30 \mathrm{~min}$ at $37^{\circ} \mathrm{C}$. In order to eliminate extracellular $P$. aeruginosa, three washes by centrifugation at $1,500 \mathrm{~g}$ for $5 \mathrm{~min}$ at room temperature in Hank's buffered saline solution were performed. After the final wash, macrophages were allowed to adhere to tissue culture flasks in Dulbecco's modified Eagle's medium supplemented with gentamicin $\left(400 \mathrm{mg} \mathrm{ml}^{-1}\right)$. Parallel control samples for counting initial number of phagocyted bacteria were washed three times by centrifugation in Hank's buffered saline solution with gentamicin (400 $\left.\mathrm{mg} \cdot \mathrm{ml}^{-1}\right)$, resuspended in equal volumes of cold sterile water, and lysis was completed by vortexing the macrophages three times for $1 \mathrm{~min}$ and incubating the macrophages on ice for 15 min before bacterial viability was assessed by plating. After one hour of incubation macrophages with internalized bacteria were harvested, lyzed as described and bacterial viability was assessed by plating. \% of survival represents \% of bacteria surviving after internalization.

\section{In vitro stress experiments}

The sensitivity of cells to oxidative stress was tested by exposing aliquots of stationary-phase cultures diluted in LB medium $\left(10^{7} \mathrm{CFU} \bullet \mathrm{ml}^{-1}\right.$; OD $\left.600=0.01\right)$ at $37^{\circ} \mathrm{C}$ to 1 $\mathrm{mM}, 10 \mathrm{mM}, 25 \mathrm{mM}, 30 \mathrm{mM}, 40 \mathrm{mM}$ and $50 \mathrm{mM}$ $\mathrm{H}_{2} \mathrm{O}_{2}$ for $1 \mathrm{~h}$. Viable cells were counted by plating them onto agar plates before and after exposure to $\mathrm{H}_{2} \mathrm{O}_{2}$, and results are expressed as survival percentages.

To study the effect of osmotic stress on the wild-type and mutant strains, stationary-phase cultures diluted in LB medium $\left(10^{7}{ }^{\circ} \mathrm{CFU} \mathrm{ml}{ }^{-1}\right.$; OD $\left.600=0.01\right)$ were grown overnight in LB containing $1.3,1.6$ or $2 \mathrm{M} \mathrm{NaCl}$ at $37^{\circ} \mathrm{C}$ with aeration, and serial dilutions of the samples were plated on LB plates to determine the CFU. Results are expressed as survival percentages.

\section{Plant virulence assays}

A lettuce leaf virulence assay was performed as described previously, [37]. Briefly, $10 \mu \mathrm{l}$ of stationaryphase cultures were diluted in LB medium $\left(10^{7}\right.$ $\mathrm{CFU} \cdot \mathrm{ml}^{-1}$; OD $\left.600=0.01\right)$, washed and resuspended in $10 \mathrm{mM} \mathrm{MgSO}_{4}$. Samples were then inoculated into the midribs of Romaine lettuce leaves. Petri dishes containing Whatman filter paper soaked with $10 \mathrm{mM} \mathrm{MgSO}_{4}$ and inoculated leaves were kept in a growth chamber at $28^{\circ} \mathrm{C}$ for five days. Symptoms were monitored daily.

\section{RNA isolation and Affymetrix GeneChip microarrays}

The wild-type and mutant strains were cultured in minimal M9 medium at $37^{\circ} \mathrm{C}$ up to early stationary phase $\left(\mathrm{OD}_{600}=0.8\right)$. Oxidative stress was generated by treatment of cultures at $\mathrm{OD}_{600}=0.8$ with $10 \mathrm{mM} \mathrm{H}_{2} \mathrm{O}_{2}$ for 15 minutes. Three independent replicates of total RNA were isolated from each strain using an RNeasy mini-kit with on-column DNase digestion (Qiagen) according to the manufacturer's instructions. For DNA microarrays, two replicates of total RNA $(10 \mu \mathrm{g})$ from each strain were used for cDNA synthesis, fragmentation, and labelling according to the Affymetrix GeneChip P. aeruginosa Genome Array Expression Analysis protocol (Affymetrix, Santa Clara, CA, USA). Briefly, random hexamer primers (final concentration, $25 \mathrm{ng} \bullet \mu \mathrm{l}^{-1}$; Invitrogen) were added to the total RNA $(10 \mu \mathrm{g})$ along with in vitro-transcribed Bacillus subtilis control spikes, as described in the Affymetrix GeneChip P. aeruginosa Genome Array Expression Analysis protocol. cDNA was synthesised using Superscript II (final concentration of 
$25 \mathrm{U} \bullet \mu \mathrm{l}^{-1}$ (Invitrogen)) according to the manufacturer's instructions under the following conditions: $25^{\circ} \mathrm{C}$ for 10 $\min , 37^{\circ} \mathrm{C}$ for $60 \mathrm{~min}, 42^{\circ} \mathrm{C}$ for $60 \mathrm{~min}$, and $70^{\circ} \mathrm{C}$ for 10 min. RNA was removed by alkaline treatment and subsequent neutralisation. The cDNA was purified using a GeneChip Sample Cleanup Module (Affymetrix) and was eluted in $12 \mu \mathrm{l}$ of EB Buffer. The cDNA was fragmented with DNase I (0.6 U per $\mu$ g of cDNA; Amersham) at $37^{\circ} \mathrm{C}$ for $10 \mathrm{~min}$ and then end-labelled with biotin-ddUTP using a GeneChip ${ }^{\circledR}$ DNA Labelling Reagent (Affymetrix) at $37^{\circ} \mathrm{C}$ for $60 \mathrm{~min}$. Proper cDNA fragmentation and biotin labelling were determined by gel mobility shift assay performed with NeutrAvadin (Pierce), followed by electrophoresis through a 4-20\% Tris-Borate gel and subsequent DNA staining with SYBR gold (Invitrogen). Fragmented labelled cDNA samples were hybridised to the array and scanned with an Affymetrix GeneChip Scanner 3000 7G.

\section{Microarray data analysis}

Raw data (CEL files) were imported into $\mathrm{R}$ statistical software [38] and normalised using the GCRMA method (GC Robust Multi-array Average (GCRMA) background adjustment, quantile normalisation, and median polish summarisation) [39]. The normalised data were tested for differences in expression using the moderated $t$-test from the limma [40] package from the Bioconductor [41] repository. Raw $P$ values were corrected using the Benjamini \& Hochberg method [42]. Microarray data were deposited in ArrayExpress database with accession number E-MEXP-3117.

\section{Real-Time PCR}

RT-PCRs were carried out in an iCycler ${ }^{\circledR}$ thermal cycler (Bio-Rad). The same RNA samples were used for realtime PCR analysis as those used for microarray analysis together with the third replicates of isolated RNA samples. One microgram of RNA served as a template for cDNA synthesis with ImProm reverse transcriptase (Promega). The cDNA was then used as a template in a PCR performed with a Sybr green I JumpStart Taq ReadyMix kit (Sigma). Three biological replicates with three technical replicates each were used for each gene. Changes in gene expression between the wild-type and mutant strain, with proC (PA0393, pyrroline-5-carboxylate reductase, prolin metabolism, a housekeeping gene) as a reference [43], were estimated by the $\Delta \Delta \mathrm{C}_{\mathrm{T}}$ method $[44,45]$.

\section{Statistical analysis}

The Student's $t$-test was performed to determine statistical significance between pairs of experimental groups. A $P$ value $<0.05$ was considered statistically significant. All experiments were repeated at least three independent times.

\section{Results and discussion}

The $\triangle p p p A-p p k A$ mutant exhibits reduced ability to grow in minimal medium and decreased production of pyoverdine

Prior to studying the effect of the $p p p A-p p k A$ mutation on the expression profiles, we first examined the $p p p A$ $p p k A$ null mutant for the production of principal virulence factors, including LasA and LasB elastase, phospholipase $\mathrm{C}$, rhamnolipids, pyocyanin, and pyoverdin, on dedicated solid media. The mutant strain demonstrated a delayed production of several virulence factors, particularly on the test plates containing glycerol where the growth of the mutant was significantly slower when compared to the wild-type strain PAO1.

Therefore, we examined growth characteristics of the wild-type and the mutant strains in both minimal and complex media. In liquid minimal medium M9 with glucose as the sole carbon source at $37^{\circ} \mathrm{C}$, the mutant strain had extended lag phase when compared to the parent strain (Figure 1A). In minimal M9 medium with glycerol as the sole carbon source, the mutant strain showed significantly reduced growth rate compared to that of the parent strain (Figure 1A). The calculated doubling time of the mutant grown in the glucose-containing media was $96( \pm 7)$ min compared to $86( \pm 6)$ min for the wild-type strain. The doubling time of the mutant grown in the glycerol-containing media was increased to $120( \pm 7)$ min compared $102( \pm 7)$ min for the parent strain. In addition, cultures of the mutant strain did not achieve the same final optical density as the parent strain in the M9 medium with glycerol. Similar growth defect was also observed in King's A and King's B media containing glycerol as carbon source (Additional file 2). In contrast, the growth characteristics of the mutant were unaltered when it was grown in either complex LB medium with a doubling time of 34 min, (Figure 1B), or CAA medium (Additional file 2). Production of the blue pigment, pyocyanin, in the mutant strain was only slightly decreased when the mutant was grown on solid LB agar (data not shown). No difference in pyocyanin production was observed in liquid LB medium. On the other hand, the mutant strain secreted a reduced amount of pyoverdine $(57 \%$ of the amount of the parent strain) when both strains were grown in liquid CAA medium (Table 2).

\section{Oxidative and osmotic stress resistance of $P$. aeruginosa is affected by the $\triangle p p p A-p p k A$ mutation}

Resistance to oxidative stress is a highly important feature for $P$. aeruginosa during its infection of a lung affected by cystic fibrosis (CF). To characterise the ability of the $p p p A-p p k A$ mutant strain to cope with stress conditions, its ability to survive $\mathrm{H}_{2} \mathrm{O}_{2}$-induced oxidative stress was examined and compared with that of the 

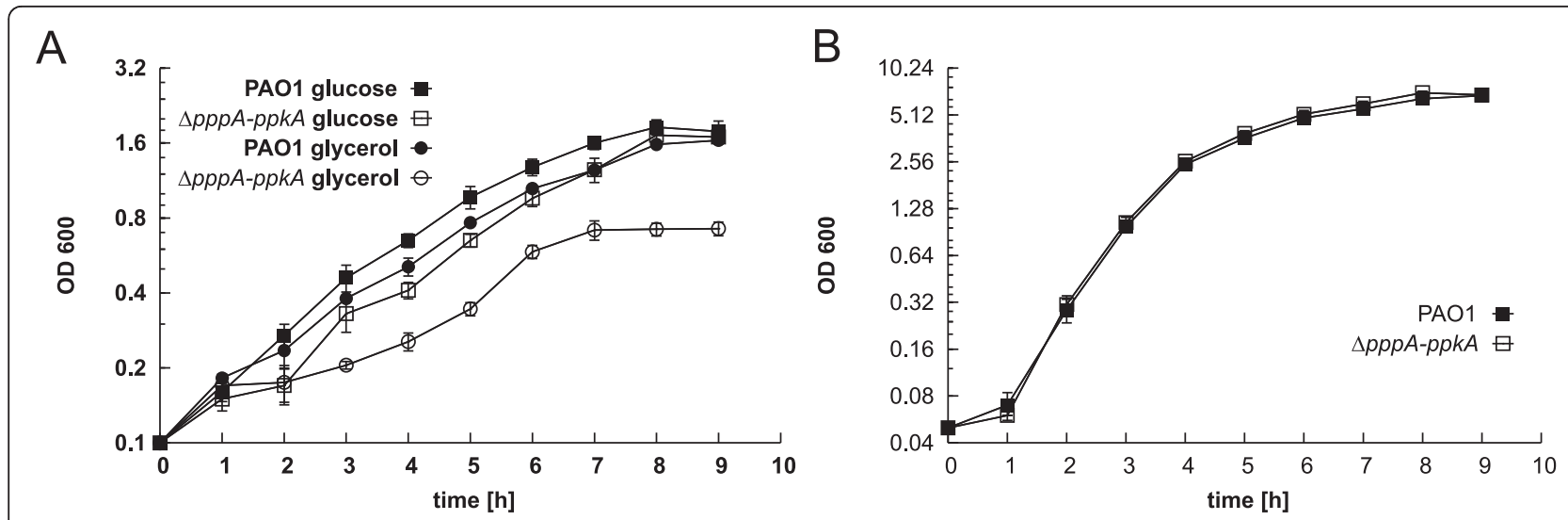

Figure 1 Characteristics of Pseudomonas aeruginosa PAO1 wild-type and $\Delta p p p A-p p k A$ strains. (A)Growth curves in M9 minimal medium with glucose or glycerol as the sole carbon source. (B) Growth curves in complex LB medium. The standard errors of the means for three independent experiments are shown. Where error bars are not shown, the standard error was within the size of the symbol.

parental strain. The sensitivity of stationary-phase cultures to oxidative stress was tested by exposing them to a range of $\mathrm{H}_{2} \mathrm{O}_{2}$ concentrations ( $1 \mathrm{mM}$ to $50 \mathrm{mM}$ ) for 1 h. Decreased survival of the $\triangle p p p A-p p k A$ mutant was observed compared to that of the wild-type beginning at $1 \mathrm{mM} \mathrm{H}_{2} \mathrm{O}_{2}$ exposure (Figure 2A). After $1 \mathrm{~h}$ of treatment with $1 \mathrm{mM}$ hydrogen peroxide, only $20 \%$ of the $\triangle p p p A-p p k A$ cells survived in comparison to $35 \%$ of the wild-type cells.

CF is characterised by disturbance in electrolyte transport which result in increased level of $\mathrm{Na}^{+}, \mathrm{Cl}^{-}$and $\mathrm{Ca}^{2+}$ [46]. Respiratory tract fluids in CF patients therefore

Table 2 Production of virulence factors by PAO1 and $\triangle p p p A-p p k A$ and MIC profiles

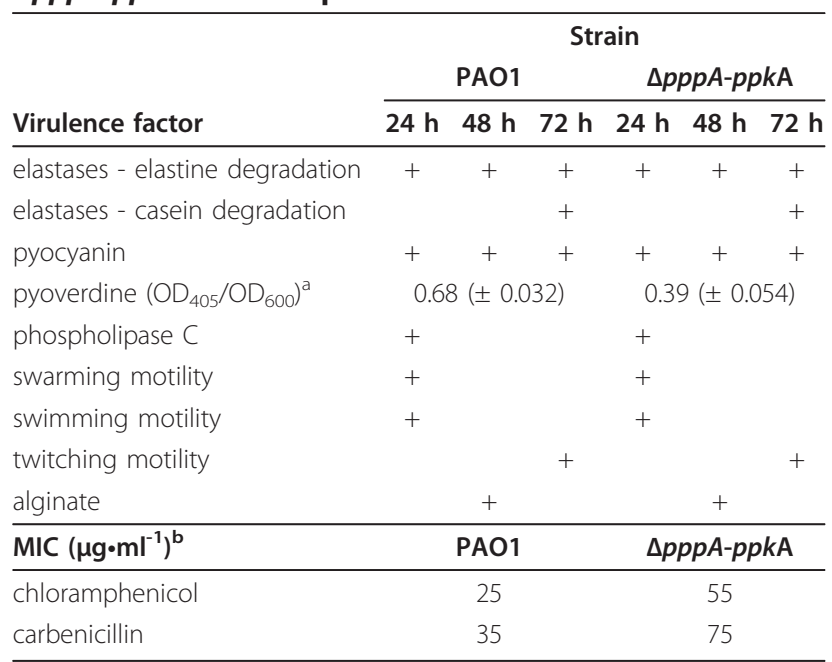

+ sign indicates positive reaction or manifestation

a The pyoverdine values are expressed as $\mathrm{OD}_{405}$ values of culture supernatants normalized to cell density at $\mathrm{OD}_{600}$. Averages based on three independent assays are presented. The numbers in the parentheses represents standard errors of the means. The differences between the mutant and wild-type strain are statistically significant $(P<0.05)$.

${ }^{b}$ The data are representative of four replicates. presents environment with high osmolarity conditions. Therefore, we tested the ability of the $\triangle p p p A-p p k A$ mutant strain to grow under high osmolarity conditions. Stationary-phase cells were treated with 1.3 to $2 \mathrm{M} \mathrm{NaCl}$. The $p p p A-p p k A$ mutant cells showed increased resistance to an increased osmotic pressure caused by a high concentration of salt (Figure 2B). After $16 \mathrm{~h}$ of exposure, there was an approximately three-fold difference in relative viability between the parent and the mutant strain.

\section{The $\triangle p p p A-p p k A$ mutant is more sensitive to} macrophage-mediated killing than the wild-type strain Decreased resistance to oxidative stress, delayed production of several virulence factors, together with the decreased growth rate of the mutant led us to measure the sensitivity of bacterial cells to macrophage-mediated killing. Both the wild-type and mutant strains were incubated with murine J774 macrophages in vitro, and intracellular bacteria were recovered to determine the number of surviving bacterial cells. As shown in Figure 3, the $\triangle p p p A-p p k A$ mutant is much more sensitive to macrophage-mediated killing than wild-type PAO1 cells, suggesting that the PpkA-PppA functional pair may regulate genes and/or proteins necessary for survival after exposure to macrophages. The mutant strain revealed a significantly decreased ability to survive (22.6\%) in comparison to the wild-type strain (70\%).

We suppose that highly increased sensitivity to oxidative killing is a major contributor to the survival of the mutant in a cellular bactericidal system because such cells will be less likely to survive the conditions inside the macrophage phagosomes.

The $\Delta p p p A-p p k A$ mutant strain is less susceptible to the antibiotics carbenicillin and chloramphenicol

$P$. aeruginosa is a major cause of nosocomial infections and is feared for its high intrinsic antibiotic resistance 


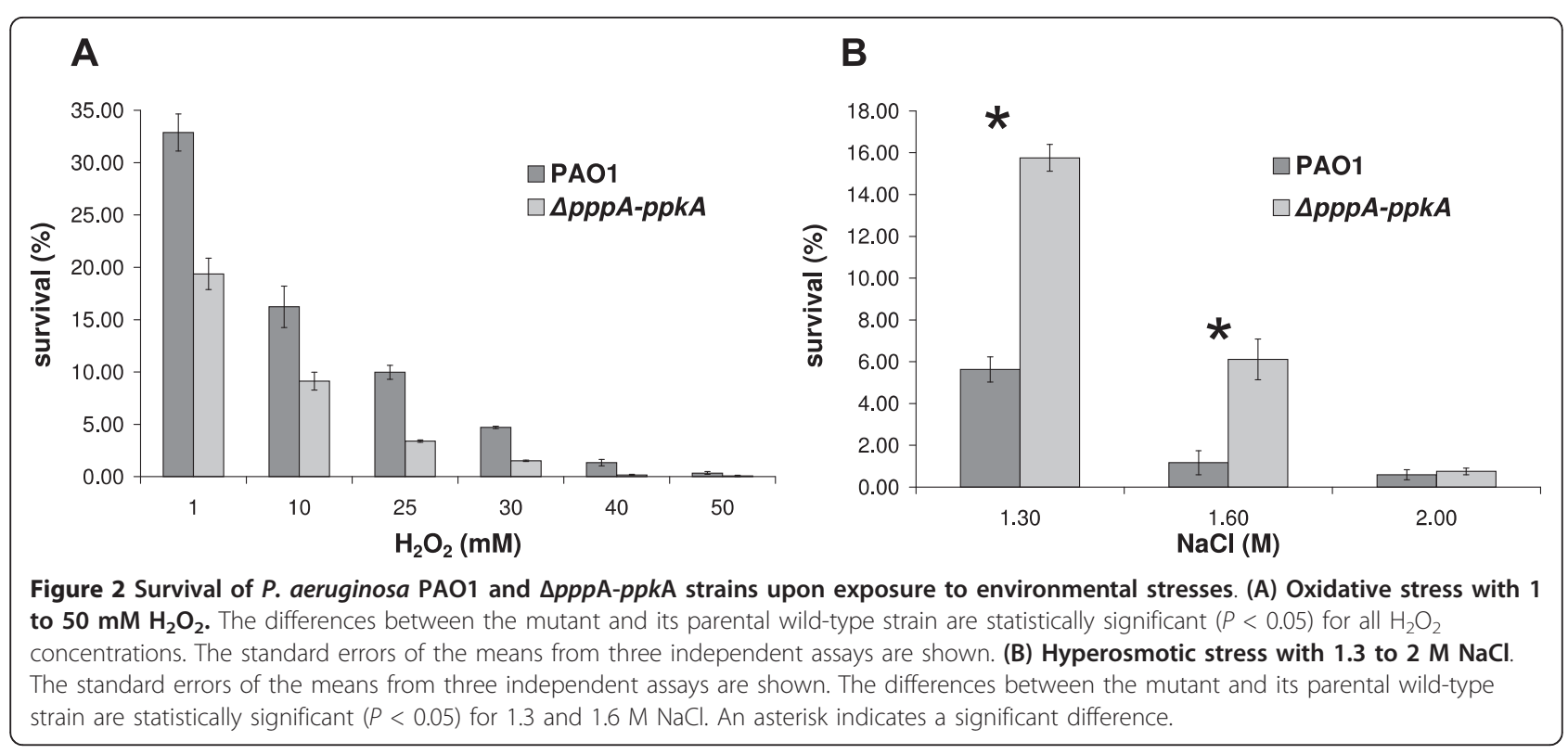

and its ability to develop multidrug resistance [47]. We analysed the sensitivity of the $\triangle p p p A-p p k A$ mutant to different classes of antibiotics commonly used for the treatment of $P$. aeruginosa infections, including carbenicillin, pefloxacin, tetracycline, and trimethoprim, as well as chloramphenicol, which is used in resistance studies. The mutant strain demonstrated a greater than two-fold decrease in sensitivity to chloramphenicol and carbenicillin compared to the wild-type strain (Table 2). No significant changes were observed for the other antibiotics tested.

Taken together, the increased resistance of the mutant strain to osmotic stress and to the antibiotics chloramphenicol and carbenicillin suggests that PppA-PpkA pair

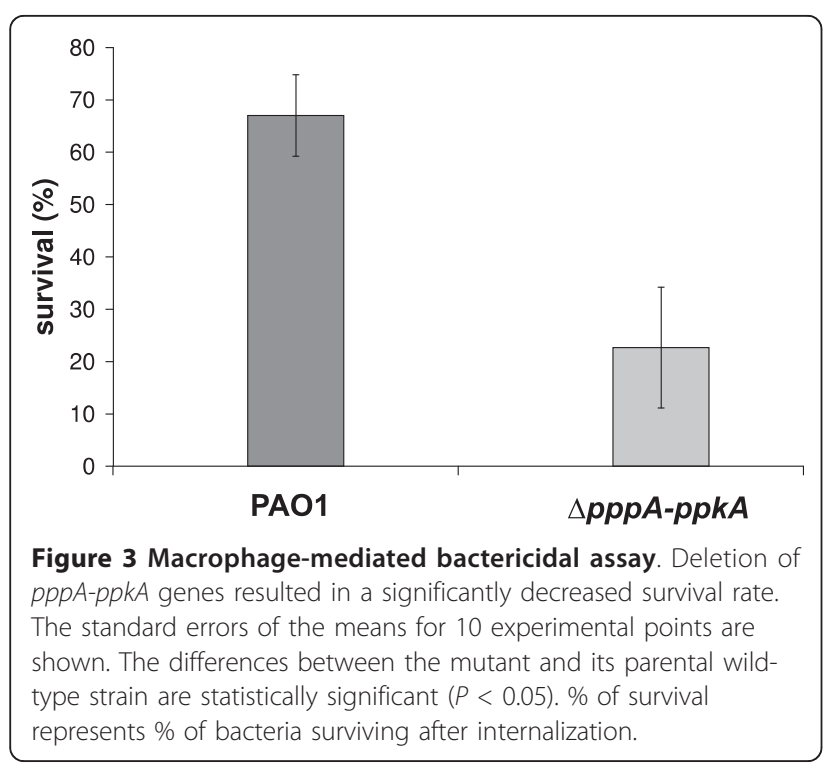

might affect cellular functions connected with membrane permeability and transport.

\section{The mutation of ppkA and pppA compromises $P$.} aeruginosa in the plant virulence model

The fact that the deletion of $p p p A-p p k A$ genes influenced stress tolerance and substantially decreased intracellular survival in the murine macrophages raised the possibility that it could also have significant implications in the ability of this mutant to cause disease. To assess the effect of the missing PppA-PpkA on the virulence of $P$. aeruginosa, we employed the lettuce leaf model of infection. Plants have previously been used as an in vivo pathogenesis model for the identification of $P$. aeruginosa virulence factors [37], and there are supporting data showing that the virulence mechanisms between plant and animal models are conserved [48].

The pathogenicity assay revealed a significant difference in the manifestation of infection symptoms caused by the mutant compared to the wild-type strain. In contrast to the wild type, which induced severe necrotic lesions three days post-infection, the mutant strain did not cause any necrosis of the leaves even after a prolonged incubation period (Figure 4). This finding indicates that the protein kinase PpkA and its cognate phosphatase PppA regulate the cellular functions that are important for virulence in the plant model of infection.

\section{Transcriptional analysis of the $P$. aeruginosa pppA-ppkA mutant}

To begin to address the genetic basis of these phenotypes, we performed a global transcription analysis of 


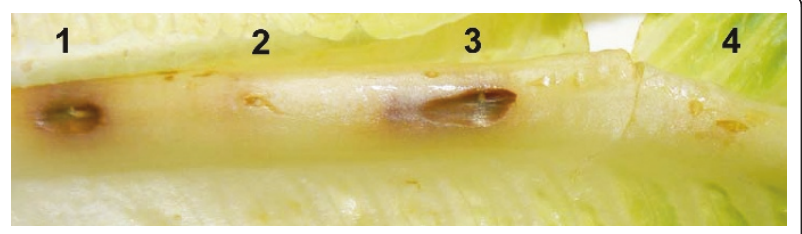

Figure 4 Plant (lettuce) infection assay with the $P$. aeruginosa PAO1 $(1,3)$ and $\triangle p p p A-p p k A(2,4)$ strains. The photograph

shows a representative example of lettuce midribs after three days of infection. Infection by PAO1 shows necrosis and tissue maceration

the $\triangle p p p A-p p k A$ mutant compared to the wild-type parental strain in early stationary phase bacteria grown in M9 medium. $P$. aeruginosa whole-genome microarray GeneChips from Affymetrix (Materials and Methods) were used throughout this study. Among the 5,570 predicted open reading frames, changes in relative transcript levels with at least a 1.7 -fold difference (with an adjusted $P$-value $<0.05$ ) were observed for 83 genes. Of the 83 genes, 70 genes showed increased expression (by 1.7- to 12.7-fold) and 13 exhibited decreased expression (by 1.7 - to 3.9 -fold) in the $\triangle p p p A-p p k A$ strain.

The affected genes were classified into three major groups constituting regulons: the oxidative stressresponsive genes [49-51], genes regulated by the stationary phase $\sigma$-factor RpoS [52] and/or by the las and $r h l$ QS systems [53,54]; genes regulated by the Pseudomonas Quinolone Signal (PQS) [55,56] (Table 3).

The microarray results were validated by the RT-PCR analysis. PA2570 (pa1L), PA4296 (pprB), PA4175 ( prpL), PA3724 (lasB), PA3622 (rpoS), PA0996 (pqsA), PA1001 (phnA), PA1317 (cyoA), PA1754 (cysB), PA1127, and PA4139 transcripts were quantified as representatives of the detected regulons and a range of mRNA level changes. In each instance, the RT-PCR results correlated well $\left(R^{2}=0.9\right)$ with those obtained from the microarrays (Table 4).

\section{Oxidative stress-responsive genes}

The genes encoding proteins involved in oxidative stress response comprised the largest category, containing genes with the most considerable alterations in relative transcription levels. These genes were identified during experiments that tested $P$. aeruginosa's response to hydrogen peroxide [49-51]. In addition, many of these genes were also found to have altered expression levels in a stationary phase $\sigma$-factor RpoS mutant [52], were found to be regulated by QS $[53,54]$, or were genes that are affected by the addition of $\mathrm{PQS}$ to $P$. aeruginosa cultures [55].

Oxidative stress-responsive genes of primary metabolism Genes of primary metabolism were previously shown to be important in combating oxidative stress through the production of cofactors such as NADPH, an essential cofactor for glutathione reductases, and alkyl hydroperoxide reductases, genes of the adaptive response to oxidative stress [57].

Repressed genes were represented by the cyoABCDE operon, which encodes cytochrome o ubiquinol oxidase, the main terminal oxidase of the electron transport chain under highly aerobic conditions [58]. On the contrary, cytochrome c oxidase complex genes $\operatorname{cox} A$, PA0107, coIII), which form the main aerobic respiration system, showed increased expression. As was shown by Salunkhe et al., the $c y o A B C D$ operon is highly upregulated during oxidative stress, whereas cox genes are repressed [51]. In our study, the regulation of these two operons was reversed, which could imply that the mutant strain is not able to cope optimally with oxidative stress. This fact could contribute to the decreased resistance of the mutant strain to oxidative stress.

Oxidative stress-responsive genes of sulphur metabolism Another important element affected by oxidative stress is sulphur, an essential part of iron-sulphur proteins which are particularly prone to oxidative damage [59]. The expression of several genes involved in sulphur metabolism is upregulated in the mutant strain, including sulphate binding proteins Sbp and CysP, sulphite reductase CysI, and the ATP sulphurylase, CysND. In addition, the hypothetical protein gene PA0284, which is upstream of $s b p$, was one of the most upregulated genes (more than 10-fold) in our study. We also observed increased expression of the cysB and CysB-regulated genes. $\mathrm{Cys} B$ transcriptional regulator is required for growth with a variety of organosulphur compounds and is known to regulate sulphur metabolism and transport genes [60,61] (see Table 3).

\section{Genes of the Rpos regulon}

Our study revealed increased expression of the rpoS gene (four-fold increase), which codes for stationary phase $\sigma$-factor RpoS, and alterations in expression of genes dependent on RpoS [52]. Many of the genes regulated by RpoS have been also reported as simultaneously affected by the las/rhl QS systems [53,54].

Among the genes of this regulon with decreased expression were those encoding the components of the type III secretion system, including PA1708-9 (popBD), as well as a gene involved in the production of type IV pili, PA4551 (pilV), which is coregulated by TTSS [28]. We observed also approximately 2 -fold decrease in expression of PA3841 (exoS) and PA0044 (exoT) genes, however, their $P$ values were above 0.1 level $(0.188$ and 0.113 , respectively). These findings corresponded to the results of Hogardt et al. [62], who observed increased expression of exoS in both $r h l$ and rpoS mutants.

The expression of the virulence factor genes PA2570 (galactophilic lectin PA-I) and PA4175 (prpL, protease IV) was increased. The remaining genes of the RpoS 
Table 3 P.aeruginosa genes affected in the $\triangle p p p A-p p k A$ mutant compared to the PAO1 wild-type strain

\begin{tabular}{|c|c|c|c|c|}
\hline Gene (Name) & $\begin{array}{c}\text { Fold } \\
\text { change }^{a}\end{array}$ & $\begin{array}{c}P- \\
\text { value }\end{array}$ & Protein (Function) ${ }^{c}$ & $\begin{array}{c}\text { Other } \\
\text { regulators }\end{array}$ \\
\hline \multicolumn{5}{|l|}{ oxidative stress } \\
\hline \multicolumn{5}{|c|}{ primary metabolism } \\
\hline PA0106 $(\operatorname{coxA})^{\mathrm{b}}$ & 2.58 & 0.177 & cytochrome c oxidase, subunit I (Energy metabolism) & RpoS, QS \\
\hline PA0107 & 3.68 & 0.091 & CHP (Energy metabolism) & Rpos, QS \\
\hline PA0108 (colll) & 2.22 & 0.038 & cytochrome c oxidase, transmembrabe helix, subunit III (Energy metabolism) & Rpos, QS \\
\hline PA1317 (cyoA) & -3.08 & 0.013 & cytochrome o ubiquinol oxidase subunit II (Energy metabolism) & QS \\
\hline PA1318 (суов) & -2.79 & 0.009 & cytochrome o ubiquinol oxidase subunit I (Energy metabolism) & QS \\
\hline PA1319 (cyoC) & -2.39 & 0.043 & cytochrome o ubiquinol oxidase subunit III (Energy metabolism) & QS \\
\hline PA1320 (cyoD) & -2.27 & 0.041 & cytochrome o ubiquinol oxidase subunit IV (Energy metabolism) & QS \\
\hline PA1321 (cyoE) & -3.86 & 0.037 & cytochrome o ubiquinol oxidase protein CyoE (Energy metabolism) & QS \\
\hline \multicolumn{5}{|c|}{ sulphur metabolism } \\
\hline PA0283 $(s b p)^{b}$ & 4.89 & 0.061 & sulfate-binding protein precursor, $\mathrm{ABC}$ transporter (Transport of small molecules) & \\
\hline PA0284 & 10.61 & 0.038 & $\mathrm{HP}$ & PQS \\
\hline PA1493 (cysP) & 4.73 & 0.004 & sulfate-binding protein of ABC transporter (Transport of small molecules) & \\
\hline PA1754 (cysB) & 1.73 & 0.022 & transcriptional regulator CysB (Amino acid biosynthesis and metabolism) & \\
\hline PA1838 (cys) $)^{\mathrm{b}}$ & 2.80 & 0.051 & sulfite reductase (Central intermediary metabolism) & \\
\hline PA3441 & 2.76 & 0.027 & Pr. molybdopterin-binding protein (Transport of small molecules) & \\
\hline PA3450 & 8.46 & 0.047 & Pr. antioxidant protein (Adaptation, protection) Probable Alkyl hydroperoxide reductase & \\
\hline PA3935 (tauD) & 1.81 & 0.037 & taurine dioxygenase (Carbon compound catabolism) & Rpos \\
\hline PA3936 $(\operatorname{tau})^{\mathrm{b}}$ & 2.92 & 0.080 & Pr. permease of $A B C$ taurine transporter (Membrane proteins; Transport of small molecules) & Rpos \\
\hline PA3938 (tauA) & 5.07 & 0.025 & Pr. periplasmic taurine-binding protein precursor (Transport of small molecules) & Rpos \\
\hline PA4442 (cysN) & 3.13 & 0.117 & $\begin{array}{l}\text { ATP sulfurylase GTP-binding subunit/APS kinase (Amino acid biosynthesis and metabolism; Central } \\
\text { intermediary metabolism) }\end{array}$ & QS \\
\hline PA4443 (cysD) $)^{b}$ & 4.86 & 0.051 & $\begin{array}{l}\text { ATP sulfurylase small subunit (Amino acid biosynthesis and metabolism; Central intermediary } \\
\text { metabolism) }\end{array}$ & QS \\
\hline \multicolumn{5}{|l|}{ others } \\
\hline PA0594 (surA) & 2.03 & 0.036 & peptidyl-prolyl cis-trans isomerase SurA (Adaptation, protection) & \\
\hline $\mathrm{PA} 1127^{\mathrm{b}}$ & -2.94 & 0.061 & Pr. oxidoreductase (Adaptation, protection; Putative enzymes) & \\
\hline \multicolumn{5}{|c|}{ RpoS regulated genes } \\
\hline$\underset{\mathrm{b}}{\mathrm{PA} 1708(\mathrm{pop} B)}$ & -2.08 & 0.070 & translocator protein PopB (Protein secretion/export apparatus) & QS, TTSS \\
\hline PA1709 (popD) & -1.82 & 0.004 & translocator protein PopD (Protein secretion/export apparatus) & QS, TTSS \\
\hline PA4551 (pill) & -2.09 & 0.008 & type 4 fimbrial biogenesis protein PilV (Motility \& Attachment) & \\
\hline PA1048 & 2.80 & 0.037 & Pr. outer membrane protein (Membrane proteins; Transport of small molecules) & \\
\hline PA1119 & 1.95 & 0.021 & Pr. outer membrane lipoprotein (Membrane proteins) & \\
\hline PA1175 (napD) & 1.88 & 0.021 & NapD protein of periplasmic nitrate reductase (Energy metabolism) & QS \\
\hline PA2204 & 1.87 & 0.014 & Pr. binding protein component of $\mathrm{ABC}$ transporter (Transport of small molecules) & PQS \\
\hline PA2223 & 2.76 & 0.021 & $\mathrm{HP}$ & \\
\hline PA2235 & 2.11 & 0.017 & $\mathrm{HP}$ & \\
\hline PA2303 & 1.80 & 0.035 & $\mathrm{HP}$ & QS \\
\hline PA2365 & 1.96 & 0.017 & $\mathrm{CHP}$ & QS \\
\hline PA2366 & 2.05 & 0.001 & $\mathrm{CHP}$ & QS \\
\hline PA2452 & 1.76 & 0.033 & $\mathrm{HP}$ & \\
\hline PA2570 (pa1L) & 2.47 & 0.049 & PA-I galactophilic lectin (Adaptation, protection; Motility \& Attachment) & QS \\
\hline PA2781 & 2.06 & 0.027 & $\mathrm{HP}$ & \\
\hline PA2939 & 4.49 & 0.018 & Pr. aminopeptidase (Putative enzymes) & QS \\
\hline PA3622 (rpoS) & 3.86 & 0.030 & sigma factor RpoS (Transcriptional regulators) & PQS \\
\hline PA3848 & 1.93 & 0.020 & $\mathrm{HP}$ & \\
\hline PA4175 (prpL) & 4.65 & 0.008 & protease IV (Secreted Factors (toxins, enzymes, alginate)) & QS \\
\hline PA4296 (pprB) & 3.69 & 0.029 & $\begin{array}{l}\text { PprB two-component response regulator (Transcriptional regulators; Two-component regulatory } \\
\text { systems; Antibiotic resistance and susceptibility) }\end{array}$ & QS \\
\hline
\end{tabular}


Table 3 P.aeruginosa genes affected in the $\Delta$ ? $\Delta$ ?pppA-ppkA mutant compared to the PA01 wild-type strain (Continued)

\begin{tabular}{|c|c|c|c|c|}
\hline PA4299 (tadD) & 2.41 & 0.086 & tadD Flp pilus assembly protein (Function Motility \& Attachment) & PprB, QS \\
\hline PA4306 (flp) & 6.69 & 0.002 & Flp Type IVb pilin (Motility \& Attachment) & PprB, QS \\
\hline \multicolumn{5}{|c|}{ QS regulated genes } \\
\hline PA0572 & 3.27 & 0.049 & $\mathrm{HP}$ & \\
\hline PA1874 & 2.02 & 0.048 & $\mathrm{HP}$ & \\
\hline PA2067 & 2.38 & 0.039 & Pr. hydrolase (Putative enzymes) & \\
\hline PA3724 (lasB) & 2.23 & 0.037 & $\begin{array}{l}\text { elastase LasB (Translation, post-translational modification, degradation; Secreted Factors (toxins, } \\
\text { enzymes, alginate)) }\end{array}$ & RpoS, PQS \\
\hline PA3922 & 11.31 & 0.038 & $\mathrm{CHP}$ & \\
\hline PA3923 & 8.11 & 0.143 & $\mathrm{HP}$ & \\
\hline PA4497 & 2.61 & 0.031 & Pr. binding protein component of $A B C$ transporter (Transport of small molecules) & \\
\hline PA5481 & 2.01 & 0.038 & $\mathrm{HP}$ & \\
\hline \multicolumn{5}{|c|}{$P Q S / M v f R$ regulon } \\
\hline PA0200 & 5.10 & 0.048 & $\mathrm{HP}$ & \\
\hline PA0201 & 5.10 & 0.048 & $\mathrm{HP}$ & \\
\hline PA0996 (pqsA) & 4.56 & 0.011 & Pr. coenzyme A ligase (Biosynthesis of cofactors, prosthetic groups and carriers) & \\
\hline PA0997 (pqsB) & 2.05 & 0.007 & $\begin{array}{l}\text { Homologous to beta-keto-acyl-acyl-carrier protein synthase (Biosynthesis of cofactors, prosthetic } \\
\text { groups and carriers) }\end{array}$ & \\
\hline PA0998 (pqsC) & 2.07 & 0.038 & $\begin{array}{l}\text { Homologous to beta-keto-acyl-acyl-carrier protein synthase (Biosynthesis of cofactors, prosthetic } \\
\text { groups and carriers) }\end{array}$ & \\
\hline PA0999 (pqsD) & 2.24 & 0.009 & 3-oxoacyl-[acyl-carrier-protein] synthase III (Biosynthesis of cofactors, prosthetic groups and carriers) & \\
\hline PA1000 (pqsE) & 2.50 & 0.016 & Quinolone signal response protein (Biosynthesis of cofactors, prosthetic groups and carriers) & \\
\hline PA1001 (phnA) & 2.54 & 0.065 & anthranilate synthase component I (Adaptation, protection) & \\
\hline PA1002 (phnB) & 2.19 & 0.071 & $\begin{array}{l}\text { anthranilate synthase component II (Adaptation, protection; Amino acid biosynthesis and } \\
\text { metabolism }\end{array}$ & \\
\hline PA3520 & 2.31 & 0.020 & $\mathrm{HP}$ & $\begin{array}{l}\text { oxidative } \\
\text { stress }\end{array}$ \\
\hline PA4377 & 3.01 & 0.022 & $\mathrm{HP}$ & \\
\hline \multicolumn{5}{|l|}{ other genes } \\
\hline PA4139 & 12.71 & 0.018 & $\mathrm{HP}$ & \\
\hline
\end{tabular}

${ }^{a}$ Fold changes represent the ratio of the expression levels in the comparison of $P$. aeruginosa $\triangle p p p A-p p k A$ and wild type PAO1. Minus (-) sign indicates a decreased expression in $\triangle p p p A-p p k A$ mutant strain; ${ }^{\mathrm{b}} p$-value $>0.05$, only genes from the same transcriptional unit are listed; ${ }^{\mathrm{C}} \mathrm{HP}-\mathrm{hypothetical}$ protein, $\mathrm{CHP}$ conserved hypothetical protein, Pr. - probable

Table 4 Transcript level comparison of P.aeruginosa genes between microarray analysis and real-time PCR analysis

\begin{tabular}{|c|c|c|c|c|c|}
\hline \multicolumn{3}{|c|}{ non-stress conditions } & \multicolumn{3}{|c|}{ oxidative stress conditions } \\
\hline \multicolumn{3}{|c|}{ mRNA level change ${ }^{a}$} & \multicolumn{3}{|c|}{ mRNA level change ${ }^{a}$} \\
\hline Gene (name) & microarray & real-time PCR & Gene (name) & microarray & real-time PCR \\
\hline PA2570 (pa1L) & 2.47 & $2.71( \pm 0.45)$ & PA4764 (fur) & -2.44 & $-1.66( \pm 0.04)$ \\
\hline PA4296 (pprB) & 3.69 & $3.71( \pm 0.39)$ & PA4227 (pchR) & 2.47 & $1.60( \pm 0.23)$ \\
\hline PA4175 (prpl) & 4.65 & $3.63( \pm 0.38)$ & PA2384 & 3.11 & $2.01( \pm 0.15)$ \\
\hline PA3724 (lasB) & 2.23 & $2.98( \pm 0.27)$ & PA1317 (cyoA) & 3.12 & $3.00( \pm 0.27)$ \\
\hline PA3622 (rpoS) & 3.86 & $4.4( \pm 0.45)$ & PA4471 (fagA) & 13.62 & $7.51( \pm 0.61)$ \\
\hline PA0996 (pqsA) & 4.56 & $2.74( \pm 0.12)$ & PA3617 (recA) & -2.26 & $-1.54( \pm 0.04)$ \\
\hline PA1001 (phnA) & 2.54 & $1.51( \pm 0.19)$ & PA3007 (lexA) & -2.02 & $-1.98( \pm 0.02)$ \\
\hline PA1317 (cyoA) & -3.08 & $-2.59( \pm 0.08)$ & PA5360 (phoB) & -2.00 & $-1.82( \pm 0.06)$ \\
\hline PA1754 (cysB) & 1.73 & $2.75( \pm 0.19)$ & PA2165 & 3.96 & $3.45( \pm 0.4)$ \\
\hline PA1127 & -2.94 & $-5.00( \pm 0.04)$ & PA0073 (tagT1) & 44.76 & $29.55( \pm 3.92)$ \\
\hline PA4139 & 12.71 & $13.3( \pm 0.71)$ & PA0072 (tagS1) & 5.15 & $3.67( \pm 0.7)$ \\
\hline
\end{tabular}

${ }^{a}$ Fold changes represent the ratio of the expression levels in the comparison of $P$. aeruginosa $\triangle p p p A-p p k A$ and wild type PAO1. Minus (-) sign indicates a decreased expression in $\triangle p p p A-p p k A$ mutant strain. 
regulon were represented mainly by genes coding for hypothetical proteins with unknown function.

Upregulated gene PA4296, which codes for the twocomponent response regulator $\mathrm{PprB}$, was shown to be regulated by both RpoS [52] and QS [53]. Consequently, the increased expression of $\mathrm{PprB}$ resulted in an increased expression of PA4299 (tadD) and PA4306 $(f l p)$. PprB was shown to positively regulate the expression of the tad locus, which is responsible for type IVb pili assembly [63]. Type IVb pili are required for adhesion to abiotic surfaces and to eukaryotic cells [63].

\section{$Q S$ and $P Q S$ regulated genes}

Another functional category of affected genes is comprised of those whose expression is mediated by the QS mechanism. However, no alterations in the expression levels of key QS regulator genes, including lasI, lasR, rhlI and rhlR, were observed. Therefore, it is likely that QS-dependent genes might be indirectly regulated by PppA-PpkA through RpoS and/or PQS, which were differentially expressed in the mutant strain. Interestingly, gene coding for elastase LasB was upregulated 2.2-fold. However, no difference in elastolytic activity was found by Elastin-Congo Red assay. In addition, a notably large increase in the expression of the genes PA3922-3923, which encode hypothetical proteins, was detected.

The genes encoding proteins involved in PQS biosynthesis comprised large category, containing seven genes that were coordinately upregulated 2.2- to 4.6fold. These genes are organised in two putative transcriptional units, $p q s A B C D E$ and $p h n A B$, and are regulated by the PQS synthesis regulator, MvfR [56].

Other affected genes were classified into a wide variety of functional categories, including genes involved in primary metabolism, the transport of small molecules, genes encoding ribosomal proteins and hypothetical genes. The most upregulated gene in our study was gene PA4139 with unknown function. It was shown by Aespedon et al. [64] as upregulated under osmotic stress conditions. Therefore, it is likely that its overexpression is related to increased resistance of the $\triangle p p p A-p p k A$ to osmotic stress. This gene is highly upregulated also under conditions of oxidative stress (13.54).

\section{Global transcriptome analysis under oxidative stress conditions}

The results of the transcriptomic profile analysis showed that a considerable number of genes involved in the oxidative stress response were differentially expressed in the mutant strain when compared to the wild-type strain. In addition, the genes from this group were the most affected genes in our study. Because phenotypic studies showed that the mutant strain had increased sensitivity to oxidative stress, these results prompted us to analyse the transcription profiles of both strains under conditions of oxidative stress.

The wild-type and mutant strains were grown under the same conditions as the first analysis up to $\mathrm{OD}_{600}=$ 0.8 , at which time sublethal oxidative stress was generated by the addition of hydrogen peroxide. Sublethal conditions were proven by measuring bacterial survival 15 min after the addition of $10 \mathrm{mM} \mathrm{H}_{2} \mathrm{O}_{2}$, which was determined by plating bacterial cultures on LB plates. No significant differences in survival rate were observed between initial and end points in either the mutant or parent strain (data not shown).

Analysis of the transcriptomes of the PAO1 and $\triangle p p p A-p p k A$ mutant strain revealed 261 genes that were significantly differentially regulated by at least two-fold with an adjusted $P$ value $\leq 0.05$ for $t$-test. Only spots that were present in at least three out of four samples were used for further analysis. Of the 261 genes, 131 genes showed increased expression (by 2- to 44.7-fold) and 130 showed decreased expression (by 2- to 7.7 -fold) in the $\triangle p p p A-p p k A$ strain.

To validate the transcriptomic data, we selected representatives of affected genes, including PA4764 (fur), PA4227 (pchR), PA2384, PA1317 (cyoA), PA4471 (fagA), PA3617 (recA), PA3007 (lexA), PA5360 (phoB), PA2165, PA0073, and PA0072, covering a range of mRNA level changes and determined their expression by independent quantitative RT PCR analysis. As shown in Table 4, the data obtained by the Affymetrix Pseudomonas GeneChip array analysis were again corroborated with RT-PCR analyses of the selected genes $\left(\mathrm{R}^{2}=0.97\right)$.

\section{Genes related to the response to oxidative stress}

As expected, a majority of affected genes were related to the oxidative stress response. A similar expression pattern has been described in previous studies of the oxidative stress response [49-51]. These genes can be classified further as genes of the adaptive stress response (e.g., genes of the SOS regulon, genes related to protective cellular mechanisms, pyocin genes), genes related to iron regulation, and primary metabolism genes.

SOS regulon DNA damage caused by hydroxyl radicals induces the expression of the SOS regulon repressor lexA gene and recA. RecA stimulates the cleavage of LexA to allow the expression of SOS regulon genes such as the inhibitors of cell division PA3008 and PA0671 or damage inducible protein P gene PA0923 $(\operatorname{din} B)$. All genes were significantly less upregulated in the mutant strain than in the wild type.

The genes related to protective cellular mechanisms The genes related to protective cellular mechanisms were represented by alkyl hydroperoxide reductase genes $a h p C, a h p F$ and PA0848. The expression levels of all of these genes were considerably less induced in the mutant than in the wild-type strain. For instance, the 
relative transcript level of the alkyl hydroperoxide reductase PA0848 gene was 5.2-fold increased in the mutant strain whereas expression was increased 29-fold in the wild type. Expression of other genes involved in the adaptation to oxidative stress encoded by the fagAfumC-orf $X$-sodM operon (PA4468-71) was also affected. The expression of this operon was shown to be repressed by ferric uptake regulation protein (Fur) and induced by iron starvation [65]. In our study, expression of the genes from this operon, as well as other Fur repressed genes, was significantly less downregulated in the mutant strain when compared to the wild type (discussed below). Our findings suggest that the response of the mutant strain to the oxidative stress is deregulated, resulting in more extensive cellular damage caused by reactive hydroxyl radicals as demonstrated by phenotypic studies.

Pyocin genes Hypothesis of increased cellular damage is further strengthened by uniformly higher transcript levels of pyocin genes (PA0614-PA0646) in the mutant strain when compared to the PAO1 parental strain. F-, $\mathrm{R}$ - and $\mathrm{S}$ - type pyocins, bacteriocins of $P$. aeruginosa, were shown to be strongly induced in response to hydrogen peroxide $[49,66]$. Pyocins cause cell death through DNA breakdown and the inhibition of lipid synthesis. Pyocin S5 has a pore-forming activity. Their production is inducible by treatments that cause DNA damage and the subsequent activation of RecA, which co-regulates the activity of many pyocin genes [67].

The oxidative stress response is intimately linked with iron homeostasis As shown by Chang et al. [49], the expression of genes regulated by $\mathrm{Fe}^{2+}$ metabolism is repressed during oxidative stress by the ferric uptake regulator, Fur, to prevent further generation of hydroxyl radicals from $\mathrm{H}_{2} \mathrm{O}_{2}$. Consistently, expression of fur gene in the wild-type strain was increased, whereas the mutant strain showed decreased expression ( $P$ value 0.086 ; verified by RT-PCR, see Table 4 and 5). As a consequence, genes of siderophore pyochelin biosynthesis, $p c h D C B$, and regulator $p c h R$ were less downregulated. The genes involved in the synthesis of siderophore pyoverdine [68] showed divergent expression which could be result of less downregulated gene PA2384 encoding global regulator responsive to $\mathrm{Fe}^{2+}$ [69]. The genes PA2381, PA2384, and PA2398 were less downregulated in the mutant strain, whereas genes PA2403-2404 and PA2409 which were not identified as PA2384-dependent [69] were more downregulated in the mutant strain. The mRNA levels of other ironregulated genes such as tonB, which codes for ferrisiderophore receptor protein Ton $B, f p v A$ gene, which encodes ferripyoverdine receptor, and the probable TonB-dependent receptor gene PA5505 were less decreased.
Oxidative stress affects the expression of primary metabolism genes Our comparison of mRNA levels of the cytochrome c oxidase genes $\operatorname{coxB}$ and coIII, components of the terminal energy-transducing respiratory complex, showed that the increase of their expression was less profound in the mutant than in the wild-type strain. A similar trend was found in the case of the cyo $A B C D E$ operon, which codes for the main terminal oxidase of the electron transport chain under high oxygen tension [70]. Similarly, the expression of other energy metabolism genes was less decreased, as was case for $n u o K$, which is part of complex I of the respiratory chain, or $\operatorname{arc} D A B$ of arginine fermentation, which is one of the major pathways of anaerobic energy metabolism in $P$. aeruginosa.

In conclusion, analysis of the transcript levels of genes related to the oxidative stress response showed that the response of the mutant strain $\triangle p p p A-p p k A$ is generally less proficient than the wild-type strain, which might result in the increased damage evidenced by the increased expression of pyocin genes and significantly reduced survival of the mutant strain when grown in the presence of a wide range of $\mathrm{H}_{2} \mathrm{O}_{2}$ concentrations.

\section{QS/RpoS regulated genes}

A number of genes identified in our study were previously found to be regulated by a quorum sensing mechanism [53]. Transcript levels of almost all of these genes were higher in the mutant strain than in the wild type. The majority of affected genes fall into the large cluster spanning the genes from PA2134 to PA2192, which were found to be regulated by the rhl quorum sensing system [53] and upregulated by exposure to human respiratory epithelia [71] in the PAO1 strain. Under oxidative stress, all 31 genes in this cluster were upregulated 2.1 - to 6.5 -fold. However, very little is known about the function of genes encoded by this cluster; 22 out of 31 affected genes are hypothetical, unclassified, and unknown. The computationally predicted operons PA2165-PA2160 and PA2151-PA2153 contain several genes related to synthesis of trehalose and glycogen. Trehalose accumulates in many bacteria as a compatible solute at high osmolarity and plays a role in the protection of proteins and membranes under various stresses (hyperosmotic, freezing, heat and oxidative stress) [72]. As shown recently by Freeman et al. [73], the deletion of orthologous operons in Pseudomonas syringae pv. tomato eliminated trehalose accumulation and reduced bacterial growth under hyperosmotic conditions. In addition, PA2144 ( $\lg \lg P$ ), which encodes glycogen phosphorylase, may participate in the synthesis of trehalose precursors. Moreover, we observed increased expression of PA2416 (treA), situated aside from the PA2134-92 cluster, which codes for periplasmic trehalase precursor. The TreA homolog in E. coli is 
Table 5 P.aeruginosa genes affected in the $\triangle p p p A-p p k A$ mutant compared to PAO1 wild-type strain under the conditions of oxidative stress

\begin{tabular}{|c|c|c|c|c|c|c|c|c|}
\hline \multirow[b]{2}{*}{$\begin{array}{l}\text { Gene } \\
\text { (name) }\end{array}$} & \multirow[b]{2}{*}{$\begin{array}{c}\text { Fold } \\
\text { change }^{b}\end{array}$} & \multirow[b]{2}{*}{$P$-value } & \multirow[b]{2}{*}{ Protein (function) ${ }^{c}$} & \multirow[b]{2}{*}{$\begin{array}{l}\text { Other } \\
\text { regulators }\end{array}$} & \multicolumn{4}{|c|}{$\begin{array}{l}\text { Normalized gene } \\
\text { signals }^{\mathrm{d}}\end{array}$} \\
\hline & & & & & $\underset{\mathrm{H}_{2} \mathrm{O}_{2}}{\Delta}$ & $\Delta$ & $\begin{array}{c}w t \\
\mathrm{H}_{2} \mathrm{O}_{2}\end{array}$ & wt \\
\hline \multicolumn{9}{|c|}{ Oxidative stress-responsive genes } \\
\hline \multicolumn{9}{|c|}{ Genes of SOS regulon } \\
\hline PA0669 & -2.85 & 0.027 & $\begin{array}{l}\text { Pr. DNA polymerase alpha chain (DNA replication, recombination, } \\
\text { modification and repair; Putative enzymes) }\end{array}$ & & 4.4 & 3.5 & 5.9 & 3.7 \\
\hline PA0671 & -3.58 & 0.000 & $\mathrm{HP}$ & & 6.1 & 2.4 & 8.0 & 2.4 \\
\hline $\begin{array}{l}\text { PA0923 } \\
(\operatorname{din} B)\end{array}$ & -2.42 & 0.037 & $\begin{array}{l}\text { DNA damage inducible protein P (DNA replication, recombination, } \\
\text { modification and repair; Adaptation, protection) }\end{array}$ & & 5.7 & 3.4 & 7.0 & 3.3 \\
\hline PA2288 & -2.24 & 0.003 & $\mathrm{HP}$ & & 8.7 & 3.2 & 9.9 & 3.7 \\
\hline $\begin{array}{l}\text { PA3007 } \\
\text { (lexA) }\end{array}$ & -2.02 & 0.023 & $\begin{array}{l}\text { repressor protein LexA (Adaptation, protection; Translation, post-translational } \\
\text { modification, degradation) }\end{array}$ & & 8.0 & 4.8 & 9.1 & 5.0 \\
\hline PA3008 & -2.26 & 0.010 & $\mathrm{HP}$ & & 7.2 & 3.1 & 8.4 & 2.8 \\
\hline $\begin{array}{l}\text { PA3617 } \\
(\text { recA })\end{array}$ & -2.26 & 0.020 & RecA protein (DNA replication, recombination, modification and repair) & & 10.1 & 7.6 & 11.2 & 7.5 \\
\hline PA0911 & 2.81 & 0.010 & $\mathrm{HP}$ & & 4.4 & 2.7 & 2.9 & 2.8 \\
\hline \multicolumn{9}{|c|}{ Genes of protective cellular mechanisms } \\
\hline $\begin{array}{l}\text { PA0139 } \\
(\text { (ahpC })^{\mathrm{a}}\end{array}$ & -1.91 & 0.090 & alkyl hydroperoxide reductase subunit C (Adaptation, protection) & & 11.9 & 11.3 & 12.8 & 10.2 \\
\hline $\begin{array}{l}\text { PA0140 } \\
\text { (ahpF) }\end{array}$ & -2.73 & 0.044 & alkyl hydroperoxide reductase subunit F (Adaptation, protection) & & 6.7 & 3.8 & 8.1 & 3.6 \\
\hline PA0848 & -7.13 & 0.001 & Pr. alkyl hydroperoxide reductase (Adaptation, protection; Putative enzymes) & & 4.9 & 2.5 & 7.7 & 2.8 \\
\hline PA2825 & -3.08 & 0.001 & Pr. transcriptional regulator (Two-component regulatory systems) & & 6.8 & 3.7 & 8.4 & 3.7 \\
\hline PA2826 & -2.32 & 0.018 & Pr. glutathione peroxidase (Adaptation, protection) & & 8.2 & 5.4 & 9.4 & 5.3 \\
\hline PA2868 & -7.76 & 0.001 & HP (Membrane proteins) & & 4.4 & 2.8 & 7.3 & 2.9 \\
\hline PA4400 & -2.60 & 0.012 & $\begin{array}{l}\text { Pr. pyrophosphohydrolase (DNA replication, recombination, modification and } \\
\text { repair) }\end{array}$ & & 3.2 & 3.0 & 4.5 & 2.9 \\
\hline $\begin{array}{l}\text { PA4612 } \\
\text { (ankB) }\end{array}$ & -2.79 & 0.042 & $\mathrm{CHP}$ & & 3.7 & 2.4 & 5.2 & 2.5 \\
\hline PA1127 & -3.07 & 0.032 & Pr. oxidoreductase (Adaptation, protection; Putative enzymes) & & 6.0 & 6.5 & 7.6 & 8.3 \\
\hline PA3287 & -6.70 & 0.001 & $\mathrm{CHP}$ & Rpos & 6.6 & 3.9 & 9.4 & 4.0 \\
\hline $\begin{array}{l}\text { PA4468 } \\
\text { (sodM) }\end{array}$ & 3.36 & 0.015 & superoxide dismutase (Adaptation, protection) & & 8.9 & 10.8 & 7.2 & 10.4 \\
\hline $\begin{array}{l}\text { PA4469 } \\
\text { (orfX) }\end{array}$ & 9.73 & 0.001 & $\mathrm{HP}$ & & 9.4 & 11.8 & 6.1 & 11.1 \\
\hline $\begin{array}{l}\text { PA4470 } \\
\text { (fumC1) }\end{array}$ & 7.86 & 0.002 & fumarate hydratase (Energy metabolism) & & 8.8 & 11.3 & 5.8 & 10.5 \\
\hline $\begin{array}{l}\text { PA4471 } \\
(\text { fagA })\end{array}$ & 13.62 & 0.005 & fagA/HP & & 9.5 & 10.7 & 5.8 & 10.3 \\
\hline \multicolumn{9}{|c|}{ Genes of pyocin synthesis } \\
\hline PA0614 & 3.60 & 0.009 & $\mathrm{HP}$ & & 6.6 & 3.9 & 4.7 & 4.0 \\
\hline PA0617 & 4.79 & 0.002 & Pr. bacteriophage protein & & 7.4 & 4.6 & 5.2 & 4.9 \\
\hline PA0618 & 3.05 & 0.027 & Pr. bacteriophage protein (Related to phage, transposon, or plasmid) & & 7.1 & 5.0 & 5.5 & 5.1 \\
\hline PA0619 & 3.53 & 0.039 & Pr. bacteriophage protein (Related to phage, transposon, or plasmid) & & 7.8 & 5.3 & 5.9 & 4.9 \\
\hline PA0620 & 2.51 & 0.035 & Pr. bacteriophage protein (Related to phage, transposon, or plasmid) & & 6.7 & 4.9 & 5.4 & 4.8 \\
\hline PA0622 & 2.56 & 0.029 & Pr. bacteriophage protein (Related to phage, transposon, or plasmid) & & 7.0 & 5.8 & 5.7 & 5.2 \\
\hline PA0623 & 3.44 & 0.042 & Pr. bacteriophage protein (Related to phage, transposon, or plasmid) & & 8.4 & 6.5 & 6.6 & 5.9 \\
\hline PA0624 & 3.01 & 0.014 & HP (Related to phage, transposon, or plasmid) & & 6.9 & 4.7 & 5.3 & 4.4 \\
\hline PA0625 & 3.02 & 0.009 & HP (Related to phage, transposon, or plasmid) & & 5.5 & 4.2 & 3.9 & 4.0 \\
\hline PA0626 ${ }^{\mathrm{a}}$ & 2.35 & 0.053 & HP (Related to phage, transposon, or plasmid) & & 5.5 & 3.8 & 4.3 & 3.5 \\
\hline PA0627 & 3.03 & 0.006 & CHP (Related to phage, transposon, or plasmid) & & 5.6 & 3.9 & 4.0 & 3.9 \\
\hline PA0628 & 3.97 & 0.004 & CHP (Related to phage, transposon, or plasmid) & & 6.8 & 4.8 & 4.8 & 4.0 \\
\hline PA0629 & 3.62 & 0.046 & CHP (Related to phage, transposon, or plasmid) & & 5.7 & 3.1 & 3.9 & 3.1 \\
\hline
\end{tabular}


Table 5 P.aeruginosa genes affected in the $\triangle$ ? $\Delta$ ?pppA-ppkA mutant compared to PAO1 wild-type strain under the conditions of oxidative stress (Continued)

\begin{tabular}{|c|c|c|c|c|c|c|c|}
\hline PA0630 & 3.88 & 0.034 & HP (Related to phage, transposon, or plasmid) & 6.8 & 4.7 & 4.8 & 4.0 \\
\hline PA0631 & 4.01 & 0.032 & HP (Related to phage, transposon, or plasmid) & 6.0 & 3.5 & 4.0 & 3.1 \\
\hline PA0632 & 2.95 & 0.001 & HP (Related to phage, transposon, or plasmid) & 4.0 & 2.4 & 2.5 & 2.4 \\
\hline PA0635 & 3.69 & 0.034 & HP (Related to phage, transposon, or plasmid) & 6.3 & 3.5 & 4.4 & 3.5 \\
\hline PA0636 & 4.46 & 0.004 & HP (Related to phage, transposon, or plasmid) & 7.4 & 5.3 & 5.2 & 4.8 \\
\hline PA0637 & 2.97 & 0.006 & CHP (Related to phage, transposon, or plasmid) & 5.1 & 3.1 & 3.5 & 2.9 \\
\hline PA0638 & 4.28 & 0.003 & Pr. bacteriophage protein (Related to phage, transposon, or plasmid) & 6.0 & 3.6 & 3.9 & 3.3 \\
\hline PA0639 & 4.28 & 0.022 & CHP (Related to phage, transposon, or plasmid) & 6.3 & 3.7 & 4.2 & 3.4 \\
\hline PA0640 & 3.42 & 0.003 & Pr. bacteriophage protein (Related to phage, transposon, or plasmid) & 4.3 & 2.3 & 2.6 & 2.3 \\
\hline PA0641 & 3.02 & 0.008 & Pr. bacteriophage protein (Related to phage, transposon, or plasmid) & 5.2 & 3.2 & 3.6 & 3.1 \\
\hline PA0643 & 2.07 & 0.011 & HP (Related to phage, transposon, or plasmid) & 3.7 & 2.5 & 2.7 & 2.4 \\
\hline PA0646 & 2.26 & 0.049 & HP (Related to phage, transposon, or plasmid) & 4.4 & 3.2 & 3.3 & 3.0 \\
\hline PA3142 & -2.62 & 0.015 & HP (Related to phage, transposon, or plasmid) & 6.7 & 5.9 & 8.1 & 5.5 \\
\hline PA3143 & -2.92 & 0.002 & HP (Related to phage, transposon, or plasmid) & 3.4 & 3.0 & 5.0 & 2.9 \\
\hline \multicolumn{8}{|c|}{ Iron metabolism related genes } \\
\hline \multicolumn{8}{|c|}{ Pyoverdine } \\
\hline PA2381 & 4.72 & 0.023 & $\mathrm{HP}$ & 6.9 & 8.4 & 4.7 & 8.7 \\
\hline PA2384 & 3.11 & 0.006 & transcriptional regulator & 7.8 & 10.8 & 6.2 & 10.5 \\
\hline PA2403 & -2.96 & 0.032 & HP (Membrane proteins) & 3.7 & 5.9 & 5.2 & 5.8 \\
\hline PA2404 & -2.19 & 0.019 & HP (Membrane proteins) & 6.3 & 8.2 & 7.4 & 7.9 \\
\hline PA2405 & -2.14 & 0.023 & $\mathrm{HP}$ & 5.0 & 7.5 & 6.1 & 7.6 \\
\hline PA2409 & -2.58 & 0.015 & $\begin{array}{l}\text { Pr. permease of ABC transporter (Membrane proteins; Transport of small } \\
\text { molecules) }\end{array}$ & 4.1 & 6.6 & 5.4 & 6.1 \\
\hline \multicolumn{8}{|c|}{ Pyochelin } \\
\hline $\begin{array}{l}\text { PA4227 } \\
(p c h R)^{a}\end{array}$ & 2.47 & 0.098 & transcriptional regulator PchR (Transcriptional regulators) & 7.0 & 7.2 & 5.7 & 7.4 \\
\hline $\begin{array}{l}\text { PA4228 } \\
(\text { pchD) }\end{array}$ & 6.12 & 0.029 & $\begin{array}{l}\text { pyochelin biosynthesis protein PchD (Transport of small molecules; Secreted } \\
\text { Factors (toxins, enzymes, alginate)) }\end{array}$ & 8.4 & 10.9 & 5.7 & 9.8 \\
\hline $\begin{array}{l}\text { PA4229 } \\
(p c h C)\end{array}$ & 5.89 & 0.059 & $\begin{array}{l}\text { pyochelin biosynthetic protein PchC (Transport of small molecules; Secreted } \\
\text { Factors (toxins, enzymes, alginate)) }\end{array}$ & 9.1 & 11.4 & 6.6 & 10.5 \\
\hline $\begin{array}{l}\text { PA4230 } \\
(p c h B)\end{array}$ & 6.08 & 0.038 & $\begin{array}{l}\text { salicylate biosynthesis protein PchB (Transport of small molecules; Secreted } \\
\text { Factors (toxins, enzymes, alginate)) }\end{array}$ & 8.3 & 11.9 & 5.7 & 11.1 \\
\hline \multicolumn{8}{|l|}{ Others } \\
\hline PA1300 & 3.86 & 0.028 & Pr. sigma-70 factor, ECF subfamily (Transcriptional regulators) & 6.4 & 7.0 & 4.5 & 7.3 \\
\hline PA4211 & 2.74 & 0.007 & $\begin{array}{l}\text { Pr. phenazine biosynthesis protein (Secreted Factors (toxins, enzymes, } \\
\text { alginate)) }\end{array}$ & 4.1 & 10.8 & 2.6 & 10.0 \\
\hline PA4570 & 5.46 & 0.011 & HP Pr. negative regulator & 9.2 & 11.9 & 6.7 & 11.8 \\
\hline PA5505 & 2.27 & 0.017 & $\begin{array}{l}\text { Pr. TonB-dependent receptor (Membrane proteins; Transport of small } \\
\text { molecules) }\end{array}$ & 3.8 & 7.0 & 2.7 & 5.8 \\
\hline $\begin{array}{l}\text { PA5531 } \\
(\operatorname{ton} B)\end{array}$ & 2.25 & 0.043 & TonB protein (Transport of small molecules) & 9.2 & 9.6 & 8.1 & 9.6 \\
\hline $\begin{array}{l}\text { PA4764 } \\
(\text { fur })^{\mathrm{a}}\end{array}$ & -2.44 & 0.086 & ferric uptake regulation protein (Transcriptional regulators) & 6.0 & 7.4 & 7.3 & 6.3 \\
\hline PA4895 & -2.35 & 0.039 & Pr. transmembrane sensor (Transcriptional regulators; Membrane proteins) & 3.2 & 3.9 & 4.4 & 4.4 \\
\hline \multicolumn{8}{|c|}{ Primary metabolism } \\
\hline $\begin{array}{l}\text { PA0105 } \\
(\text { COXB) }\end{array}$ & -2.38 & 0.048 & cytochrome c oxidase, subunit II (Energy metabolism) & 8.9 & 5.7 & 10.1 & 4.9 \\
\hline $\begin{array}{l}\text { PA0108 } \\
(\mathrm{Colll})^{\mathrm{a}}\end{array}$ & -1.89 & 0.062 & cytochrome c oxidase, subunit III (Energy metabolism) & 9.4 & 6.0 & 10.3 & 4.6 \\
\hline PA0250 & -4.17 & 0.001 & $\mathrm{CHP}$ & 5.7 & 5.4 & 7.8 & 5.6 \\
\hline $\begin{array}{l}\text { PA1756 } \\
\text { (cysh) }\end{array}$ & -2.16 & 0.007 & $\begin{array}{l}\text { 3'-phosphoadenosine-5'-phosphosulfate reductase (Amino acid biosynthesis } \\
\text { and metabolism) }\end{array}$ & 4.0 & 5.3 & 5.1 & 4.5 \\
\hline $\begin{array}{l}\text { PA2611 } \\
\text { (cysG) }\end{array}$ & -2.02 & 0.008 & siroheme synthase (Biosynthesis of cofactors, prosthetic groups and carriers) & 4.9 & 4.7 & 5.9 & 4.8 \\
\hline PA2869 & -3.36 & 0.000 & $\mathrm{HP}$ & 2.6 & 2.6 & 4.4 & 2.7 \\
\hline
\end{tabular}


Table 5 P.aeruginosa genes affected in the $\triangle$ ? $\Delta$ ?pppA-ppkA mutant compared to PAO1 wild-type strain under the conditions of oxidative stress (Continued)

\begin{tabular}{|c|c|c|c|c|c|c|c|}
\hline${\mathrm{PA} 0603^{\mathrm{a}}}$ & 2.50 & 0.095 & $\begin{array}{l}\text { Pr. ATP-binding component of ABC transporter (Transport of small } \\
\text { molecules) }\end{array}$ & 7.9 & 4.8 & 6.5 & 4.1 \\
\hline PA0604 & 3.46 & 0.012 & $\begin{array}{l}\text { Pr. binding protein component of } A B C \text { transporter (Transport of small } \\
\text { molecules) }\end{array}$ & 5.0 & 2.7 & 3.2 & 2.5 \\
\hline PA0605 & 2.83 & 0.003 & $\begin{array}{l}\text { Pr. permease of ABC transporter (Membrane proteins); Transport of small } \\
\text { molecules) }\end{array}$ & 5.6 & 3.0 & 4.1 & 3.0 \\
\hline $\begin{array}{l}\text { PA1317 } \\
(\text { cyoA) }\end{array}$ & 3.12 & 0.026 & cytochrome o ubiquinol oxidase subunit II (Energy metabolism) & 7.1 & 8.3 & 5.5 & 9.7 \\
\hline $\begin{array}{l}\text { PA1318 } \\
(\text { cyoB })\end{array}$ & 2.24 & 0.032 & cytochrome o ubiquinol oxidase subunit I (Energy metabolism) & 4.4 & 5.8 & 3.2 & 7.3 \\
\hline $\begin{array}{l}\text { PA1319 } \\
\text { (cyoC) }\end{array}$ & 3.10 & 0.026 & cytochrome o ubiquinol oxidase subunit III (Energy metabolism) & 5.2 & 6.1 & 3.6 & 7.4 \\
\hline $\begin{array}{l}\text { PA1321 } \\
(\text { cyoE })\end{array}$ & 2.21 & 0.040 & cytochrome o ubiquinol oxidase protein CyoE (Energy metabolism) & 5.7 & 5.7 & 4.6 & 7.5 \\
\hline $\begin{array}{l}\text { PA2646 } \\
\text { (nuoK) }\end{array}$ & 2.24 & 0.043 & NADH dehydrogenase I chain K (Energy metabolism) & 4.9 & 5.4 & 3.7 & 5.5 \\
\hline PA3441 & 7.35 & 0.006 & Pr. molybdopterin-binding protein (Transport of small molecules) & 9.5 & 7.2 & 6.6 & 5.6 \\
\hline PA3442 ${ }^{\mathrm{a}}$ & 2.69 & 0.092 & $\begin{array}{l}\text { Pr. ATP-binding component of ABC transporter (Transport of small } \\
\text { molecules) }\end{array}$ & 7.5 & 6.4 & 6.0 & 5.1 \\
\hline $\begin{array}{l}\text { PA5170 } \\
(\operatorname{arcD})\end{array}$ & 4.45 & 0.049 & $\begin{array}{l}\text { arginine/ornithine antiporter (Amino acid biosynthesis and metabolism; } \\
\text { Membrane proteins; Transport of small molecules) }\end{array}$ & 8.1 & 7.4 & 6.0 & 6.7 \\
\hline $\begin{array}{l}\text { PA5171 } \\
(\operatorname{arcA})\end{array}$ & 2.67 & 0.019 & arginine deiminase (Amino acid biosynthesis and metabolism) & 7.6 & 9.0 & 6.2 & 8.5 \\
\hline $\begin{array}{l}\text { PA5172 } \\
(\operatorname{arcB})\end{array}$ & 2.66 & 0.026 & $\begin{array}{l}\text { ornithine carbamoyltransferase, catabolic (Amino acid biosynthesis and } \\
\text { metabolism) }\end{array}$ & 7.3 & 8.8 & 5.9 & 8.5 \\
\hline \multicolumn{8}{|l|}{ Others } \\
\hline PA3237 & -2.89 & 0.004 & $\mathrm{HP}$ & 3.9 & 2.4 & 5.5 & 2.5 \\
\hline $\begin{array}{l}\text { PA0157 } \\
(\text { triB) }\end{array}$ & 2.28 & 0.001 & $\begin{array}{l}\text { Pr. RND efflux membrane fusion protein precursor (Transport of small } \\
\text { molecules) }\end{array}$ & 6.6 & 5.3 & 5.4 & 5.4 \\
\hline
\end{tabular}

QS regulated genes

PA2134-92 locus

$\begin{array}{llll}\text { PA2134 } & 4.16 & 0.032 & \text { HP } \\ \text { PA2135 } & 2.85 & 0.027 & \text { Pr. transporter (Membrane proteins; Transport of small molecules) } \\ \text { PA2136 } & 3.01 & 0.004 & \text { HP } \\ \text { PA2139 } & 6.55 & 0.001 & \text { HP } \\ \text { PA2140 } & 3.74 & 0.018 & \text { Pr. metallothionein (Central intermediary metabolism) } \\ \text { PA2141 } & 5.64 & 0.003 & \text { HP } \\ \text { PA2142 } & 4.05 & 0.029 & \text { Pr. short-chain dehydrogenase (Putative enzymes) } \\ \text { PA2144 } & 4.01 & 0.008 & \text { glycogen phosphorylase (Cell wall/LPS/capsule) } \\ \text { glgP) } & & & \\ \text { PA2148 } & 4.37 & 0.016 & \text { CHP (Membrane proteins) } \\ \text { PA2149 } & 6.01 & 0.011 & \text { HP } \\ \text { PA2150 } & 5.76 & 0.000 & \text { CHP } \\ \text { PA2151 } & 3.46 & 0.041 & \text { CHP } \\ \text { PA2156 } & 2.40 & 0.001 & \text { CHP } \\ \text { PA2157 } & 4.03 & 0.002 & \text { HP } \\ \text { PA2158 } & 4.51 & 0.019 & \text { Pr. alcohol dehydrogenase (Zn-dependent) (Putative enzymes) } \\ \text { PA2159 } & 2.89 & 0.062 & \text { CHP } \\ \text { PA2161 } & 3.33 & 0.081 & \text { HP } \\ \text { PA2162 } & 2.14 & 0.049 & \text { Pr. glycosyl hydrolase (Putative enzymes) } \\ \text { PA2163 } & 2.79 & 0.023 & \text { HP } \\ \text { PA2164 } & 4.66 & 0.026 & \text { Pr. glycosyl hydrolase (Putative enzymes) } \\ \text { PA2165 } & 3.96 & 0.008 & \text { Pr. glycogen synthase (Energy metabolism) } \\ \text { PA2167 } & 2.72 & 0.049 & \text { HP } \\ \text { PA2168 } & 2.78 & 0.049 & \text { HP }\end{array}$

$\begin{array}{llll}8.7 & 5.6 & 6.6 & 5.7 \\ 4.7 & 3.0 & 3.2 & 3.4 \\ 4.1 & 2.3 & 2.5 & 2.4 \\ 6.8 & 2.6 & 4.1 & 2.8 \\ 6.8 & 3.0 & 4.9 & 3.4 \\ 6.9 & 2.8 & 4.4 & 2.8 \\ 7.7 & 3.9 & 5.7 & 4.3 \\ 6.8 & 3.7 & 4.8 & 3.6 \\ & & & \\ 8.1 & 4.2 & 6.0 & 4.3 \\ 9.4 & 4.6 & 6.9 & 4.7 \\ 5.5 & 2.4 & 2.9 & 2.4 \\ 7.0 & 3.6 & 5.2 & 3.4 \\ 3.6 & 2.4 & 2.4 & 2.4 \\ 6.2 & 3.4 & 4.2 & 3.8 \\ 7.9 & 4.1 & 5.7 & 4.0 \\ 5.9 & 3.2 & 4.4 & 3.7 \\ 5.1 & 4.3 & 3.4 & 4.2 \\ 6.2 & 4.6 & 5.1 & 4.8 \\ 8.3 & 5.4 & 6.8 & 5.3 \\ 9.6 & 5.7 & 7.4 & 5.1 \\ 10.3 & 5.5 & 8.3 & 5.3 \\ 6.5 & 3.0 & 5.1 & 2.5 \\ 8.0 & 4.6 & 6.5 & 4.3\end{array}$


Table 5 P.aeruginosa genes affected in the $\triangle$ ? $\Delta$ ?pppA-ppkA mutant compared to PAO1 wild-type strain under the conditions of oxidative stress (Continued)

\begin{tabular}{|c|c|c|c|c|c|c|c|}
\hline PA2178 & 3.55 & 0.004 & $\mathrm{HP}$ & & 6.6 & 3.3 & 4.8 \\
\hline PA2179 & 3.16 & 0.023 & $\mathrm{HP}$ & & 5.7 & 2.5 & 4.1 \\
\hline PA2180 & 3.05 & 0.032 & $\mathrm{HP}$ & & 8.3 & 4.2 & 6.6 \\
\hline PA2181 & 2.99 & 0.001 & $\mathrm{HP}$ & & 5.3 & 2.6 & 3.7 \\
\hline PA2184 & 5.62 & 0.007 & $\mathrm{CHP}$ & & 7.6 & 4.9 & 5.1 \\
\hline PA2187 & 3.01 & 0.038 & $\mathrm{HP}$ & & 7.2 & 3.4 & 5.6 \\
\hline PA2188 & 2.14 & 0.032 & Pr. alcohol dehydrogenase (Zn-dependent) (Putative enzymes) & & 4.2 & 2.8 & 3.1 \\
\hline PA2192 & 2.72 & 0.020 & $\mathrm{CHP}$ & & 5.4 & 2.9 & 4.0 \\
\hline \multicolumn{8}{|c|}{ QS regulated virulence factors } \\
\hline $\begin{array}{l}\text { PA1246 } \\
(\text { aprD })^{\mathrm{a}}\end{array}$ & 2.10 & 0.066 & $\begin{array}{l}\text { alkaline protease secretion protein AprD (Secreted Factors (toxins, enzymes, } \\
\text { alginate); Protein secretion/export apparatus) }\end{array}$ & & 6.4 & 8.0 & 5.4 \\
\hline $\begin{array}{l}\text { PA1248 } \\
(a p r F)^{\mathrm{a}}\end{array}$ & 2.05 & 0.072 & $\begin{array}{l}\text { alkaline protease secretion protein AprF (Protein secretion/export apparatus; } \\
\text { Secreted Factors (toxins, enzymes, alginate)) }\end{array}$ & & 6.4 & 6.8 & 5.4 \\
\hline $\begin{array}{l}\text { PA1249 } \\
\text { (aprA) }\end{array}$ & 3.25 & 0.042 & $\begin{array}{l}\text { alkaline metalloproteinase precursor (Secreted Factors (toxins, enzymes, } \\
\text { alginate) }\end{array}$ & PhoB & 6.6 & 8.3 & 4.9 \\
\hline $\begin{array}{l}\text { PA2300 } \\
\text { (chiC) }\end{array}$ & 6.31 & 0.004 & chitinase (Carbon compound catabolism) & Rpos & 5.7 & 8.3 & 3.1 \\
\hline $\begin{array}{l}\text { PA2570 } \\
\text { (pa1L) }\end{array}$ & 3.37 & 0.025 & PA-I galactophilic lectin (Adaptation, protection; Motility \& Attachment) & Rpos & 6.6 & 5.8 & 4.8 \\
\hline $\begin{array}{l}\text { PA3477 } \\
(\text { rh/R })\end{array}$ & 2.25 & 0.013 & $\begin{array}{l}\text { transcriptional regulator RhIR (Adaptation, protection; Transcriptional } \\
\text { regulators) }\end{array}$ & Rpos & 8.9 & 9.2 & 7.8 \\
\hline $\begin{array}{l}\text { PA3724 } \\
\text { (lasB) }\end{array}$ & 2.37 & 0.042 & $\begin{array}{l}\text { elastase LasB (Translation, post-translational modification, degradation; } \\
\text { Secreted Factors (toxins, enzymes, alginate)) }\end{array}$ & Rpos PQS & 6.0 & 8.4 & 4.7 \\
\hline
\end{tabular}

PhoB

regulon

PA2364 -2.65

PA2931 $\quad-2.05 \quad 0.008$ transcriptional regulator (Transcriptional regulators)

$\begin{array}{lllll}\text { RpoS } & 5.6 & 5.4 & 7.0 & 5.2\end{array}$

$\begin{array}{llll}5.1 & 3.8 & 6.2 & 3.0\end{array}$

(CifR)

PA3006 $-2.31 \quad 0.049$ transcriptional regulator PsrA (Transcriptional regulators)

(psrA)

PA5360 $\quad-2.00 \quad 0.004$ two-component response regulator PhoB (Transcriptional regulators; Two-

(phoB) component regulatory systems)

PA5365 - - $1.76 \quad 0.012$ phosphate uptake regulatory protein PhoU (Membrane proteins;

(phol) Transcriptional regulators)

PA5369 -2.03 0.049 phosphate ABC transporter, periplasmic phosphate-binding protein

(pstS) (Transport of small molecules)

$\begin{array}{llll}\text { PA3309 } & 3.88 & 0.010 \quad \mathrm{CHP}\end{array}$

CHP

\begin{tabular}{llll}
5.4 & 3.6 & 6.5 & 4.2 \\
5.1 & 4.4 & 6.3 & 5.1 \\
4.6 & 3.5 & 5.6 & 3.5 \\
6.1 & 4.1 & 6.9 & 4.1 \\
8.3 & 5.2 & 9.3 & 5.3 \\
7.7 & 7.3 & 5.7 & 7.2 \\
\hline
\end{tabular}

Other

genes

PA3757

$-5.59$

0.005

$\begin{array}{llll}\text { PA2414 } & 2.70 & 0.039 & \text { L-sorbosone dehydrogenase (Carbon compound catabolism) }\end{array}$

PA2416 $\quad 3.31 \quad 0.025$ periplasmic trehalase precursor (Carbon compound catabolism)

(treA)

PA4139

$13.54 \quad 0.044 \quad H P$

$\begin{array}{llll}3.4 & 3.4 & 5.9 & 2.8 \\ 6.2 & 5.2 & 4.8 & 4.5 \\ 6.5 & 3.7 & 4.8 & 4.0 \\ & & & \\ 7.2 & 8.0 & 3.5 & 4.2\end{array}$

${ }^{a} p$-value $>0.05$, only genes from the same transcriptional unit are listed; ${ }^{\mathrm{b}}$ Fold changes represent the ratio of the expression levels in the comparison of $P$. aeruginosa $\triangle p p p A-p p k A$ and wild type PAO1 under the conditions of oxidative stress. Minus (-) sign indicates a decreased expression in $\triangle p p p A-p p k A$ mutant strain; ${ }^{c} \mathrm{HP}$ - hypothetical protein, CHP- conserved hypothetical protein, Pr. - probable ${ }^{\mathrm{d}}$ Means of normalized gene signals of two replicates; $\Delta \mathrm{H}_{2} \mathrm{O}_{2} / \Delta$ - mutant strain signal intensities treated/untreated with $10 \mathrm{mM} \mathrm{H}_{2} \mathrm{O}_{2} ;$ wt $\mathrm{H}_{2} \mathrm{O}_{2} /$ wt - wild-type PAO1 strain signal intensities treated/untreated with 10 mM $\mathrm{H}_{2} \mathrm{O}_{2}$

an osmotically inducible enzyme necessary for the catabolism of trehalose [74]. In addition, gene PA3757 coding for probable trehalose operon repressor was significantly downregulated in the mutant strain (5.59-fold) which could result in observed increased expression of other trehalose metabolism-related genes. Therefore, it is possible that increased expression of trehalose biosynthetic genes in the mutant strain could be responsible for the increased resistance of the mutant to the hyperosmotic stress, as we showed in the phenotypic analyses. 
Among the other affected QS-regulated genes, many of which are also regulated by stationary phase $\sigma$-factor RpoS, were genes encoding virulence factors such as alkaline protease AprA and components of its secretion apparatus AprD and AprF, the chiC gene coding for chitinase, the elastase LasB gene, and pa1L, which encodes PA-I galactophilic lectin. The rest of the QScontrolled genes were either genes of primary metabolism or hypothetical genes.

\section{Genes of the Pho regulon}

Several genes associated with phosphate acquisition showed differential transcription in the mutant strain under conditions of oxidative stress (Table 5). The genes pstS and phoU of the phosphate-specific membrane transport complex PstSCAB-PhoU, phoB, the principal two-component response regulator [75], as well as some other genes of the Pho regulon were less upregulated in the mutant than in the wild-type response. Expression of the Pho regulon, under the conditions of inorganic phosphate $\left(P_{i}\right)$ limitation, is activated by the binding of PhoB to a consensus $\mathrm{PHO}$ box sequence within the promoters of Pho regulon genes [76]. Consequently, we identified affected genes with predicted $\mathrm{PHO}$ boxes encoding transcriptional regulators PsrA [77] and CifR [78], aprA gene, which codes for alkaline protease, and several hypothetical genes.

Pho regulon genes were shown to be induced in $P$. aeruginosa $\mathrm{PAO} 1$ after the exposure to human respiratory epithelia [71,79]. As shown by Jensen et al. [76], PhoB regulates the expression of the QS regulator RhlR and PHO box consensus sequences were found in the promoters of many virulence regulators and genes. Furthermore, PstS protein was found to be involved in adherence to and disruption of the integrity of cultured intestinal epithelial cell monolayers [80]. These findings suggest that tight regulation of phosphate acquisition within the host tissues through the functional transport/ regulatory Pst-Pho complex could play an indispensable role in the virulence of $P$. aeruginosa.

In summary, our microarray analysis of the transcription profile of a $p p p A-p p k A$ mutant under conditions of oxidative stress revealed that the response of the mutant strain to the oxidative stress is less coordinated than that of the wild-type strain. For example, in the mutant strain iron metabolism genes are less downregulated. On the contrary, the oxidative stress-adaptation genes as well as the genes of SOS regulon are less upregulated. These alterations in the cellular response to stress conditions would result in greater extent of damage, as manifested by increased expression of pyocin genes, and above all, by a significantly reduced survival of the mutant strain grown under the wide range of hydrogen peroxide concentrations. Furthermore, in addition to the genes regulated directly or indirectly by the oxidative stress, we identified differentially regulated genes of QS regulon along with the closely connected RpoS regulon. Overexpressed locus PA2134-92, which probably encodes several genes involved in trehalose biosynthesis, could play a role in the increased resistance of the mutant strain to hyperosmotic stress. The Pho regulon genes, downregulated in the mutant strain, were shown to be upregulated in the human respiratory epithelia. This fact suggests that phosphate availability and the regulation of phosphate acquisition can influence the virulence of $P$. aeruginosa.

\section{Complementation restores expression of affected genes to the wild-type level}

To exclude the possibility of either polar or suppressor mutations in the mutant, we constructed complementation strains with wt $p p p A-p p k A$ genes expressed ectopically. By using the mini-Tn7 vector, pUC18mini-Tn7T-LAC, with a tac promoter, $p p p A-p p k A$ genes were inserted into the chromosome of $\triangle p p p A$ ppkA mutant creating $\Delta:: \operatorname{tn} 7$ TLACpak strain. A modified wild-type strain, PAO1::tn7TLAC, and mutant strain, $\Delta:$ :tn7TLAC, with an inserted empty miniTn7T-LAC cassette were used as controls (see Material and Methods).

By using quantitative real-time PCR analysis, we compared the expression levels of $p p p A$ and $p p k A$ in strains PAO1::tn7TLAC and $\triangle:: \operatorname{tn} 7$ TLACpak either uninduced or induced by $1 \mathrm{mM}$ IPTG. Three independent replicates of total RNA from each strain were isolated from cultures grown in minimal M9 medium up to $\mathrm{OD}_{600}=$ 0.8 . As shown in Table 6, the expression of $p p p A$ and $p p k A$ in the $\Delta:: \operatorname{tn} 7$ TLACpak increased approximately 30 -fold upon induction with $1 \mathrm{mM}$ IPTG when compared to the PAO1::tn7TLAC strain. Interestingly, $p p p A$ and $p p k A$ were expressed in the $\Delta:: \operatorname{tn} 7$ TLACpak strain even without induction with IPTG, and the transcript levels were comparable to those detected in the PAO1:: tn7TLAC strain. Therefore, further qRT-PCR analysis of genes affected in the $\triangle p p p A-p p k A$ mutant was performed with cultures without the presence of an inducer. The results showed that the expression of all selected genes in the complemented $\Delta:: \operatorname{tn} 7$ TLACpak strain recovered approximately wild-type levels (Figure 5), and thus confirmed the role of PppA-PpkA in their regulation.

To confirm further complementation of the mutant strain we performed several phenotypic analyses. Growth analysis of the complemented strain $\Delta:$ : tn7TLACpak in M9 minimal medium with glucose showed intermediate phenotype when compared to the PAO1::tn7TLAC and $\Delta::$ tn7TLAC strains. The complemented strain recovered approximately wild-type (PAO1::tn7TLAC) levels resistance to both oxidative 
Table 6 Fold change of expression of pppA and ppkA genes in the strains PAO1::tn7TLAC, $\triangle:: \operatorname{tn} 7 T L A C$ and $\Delta::$ tn7TLACpak

\begin{tabular}{ccc}
\hline \multirow{2}{*}{ Gene } & \multicolumn{2}{c}{ Fold change $^{\mathrm{a}}$} \\
\cline { 2 - 3 } & $\begin{array}{c}\Delta:: \text { tn7TLACpak+IPTG/ } \\
\text { PAO1::tn7TLAC+IPTG }\end{array}$ & $\begin{array}{l}\Delta:: \text { tn7TLACpak/ } \\
\text { PAO1::tn7TLAC }\end{array}$ \\
\hline pppA & $27.49 \pm 5.36$ & $-1.32 \pm 0.34^{\mathrm{b}}$ \\
ppkA & $35.16 \pm 6.76$ & $1.59 \pm 0.67^{\mathrm{b}}$ \\
\hline
\end{tabular}

${ }^{a}$ Fold changes represent the ratio of the expression levels in the comparison of $P$. aeruginosa $\Delta::$ tn7TLACpak or $\triangle::$ tn7TLAC, respectively, and PAO1::tn7TLAC. Minus (-) sign indicates a decreased expression in $\Delta$ strains; ${ }^{\mathrm{b}}$ Fold change not significantly different from PAO1::tn7TLAC $(P>0.05) ;+$ IPTG - induction of expression with $1 \mathrm{mM}$ IPTG

and osmotic stress conditions. The $\Delta$ ::tn7TLACpak strain significantly rescued the defect in pyoverdine production. In addition, the $\Delta::$ tn7TLACpak strain was able to induce necrosis of the lettuce leaves in the plant virulence model, although to the lesser extent than the PAO1::tn7TLAC strain. All figures documenting complemented mutant phenotypes are provided as Additional file 3.

\section{Conclusions}

Our microarray analysis of the transcription profiles of a $p p p A-p p k A$ mutant revealed that the posttranslational modification of an as-yet-unidentified target(s) affects the expression of many functionally different genes in $P$. aeruginosa. The pleiotropic effect of the mutation is noteworthy. Among the most dramatically affected genes were those included in the cellular response to

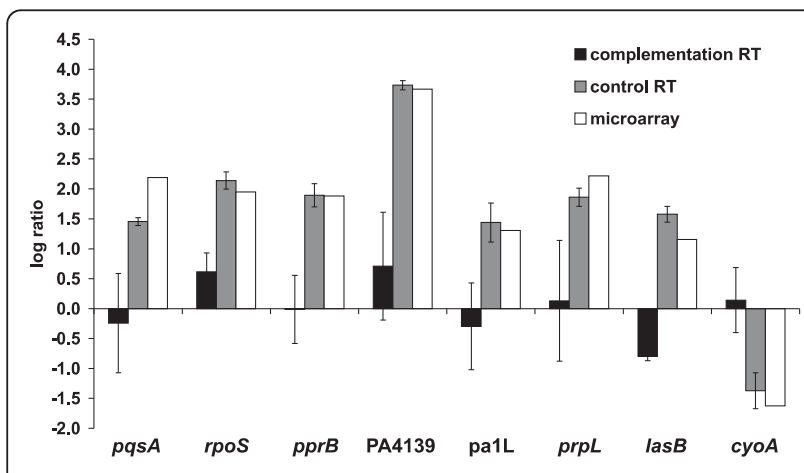

Figure 5 Transcript levels of selected genes in the complemented mutant strain $\Delta:$ :tn7TLACpak compared to the PA01::tn7TLAC strain, and mutant $\triangle p p p A-p p k A$ strain versus wild type as observed from microarray and control real-time PCR analysis. For real-time PCR analysis, mean values of three biological replicates are given. Error bars represent the standard error of the mean. Complementation RT - transcript levels of the indicated genes in the $\triangle::$ tn7TLACpak compared to the PAO1:: tn7TLAC strain assessed by real-time PCR; control RT - transcript levels of indicated genes in the $\triangle p p p A-p p k A$ mutant compared to the PAO1 wild type assessed by real-time PCR; microarray transcript levels of indicate genes in the $\triangle p p p A-p p k A$ mutant compared to the PAO1 wild type assessed by microarray analysis. oxidative stress. The range of this adaptive response involving all affected genes was far inferior in the mutant when compared to the wild-type strain. Therefore, the increased susceptibility of the mutant to oxidative stress conditions could be a factor affecting survival in a cellular bactericidal system.

Due to the transmembrane topology of PpkA and the presence of an extracellular sensor domain containing a single von Willebrand factor A-domain (VWA domain), we hypothesised that PpkA could transmit environmental signals into the cell. Recent studies have demonstrated that ligand binding to potential extracellular sensor domains of bacterial PKs might be a prerequisite for kinase dimerisation and, consequently, for activation during an autophosphorylation process $[81,82]$. The phenomenon of ligand recognition-induced dimerisation of PpkA followed by autophosphorylation has been recently described [21]. In addition, it was showed that interaction of TagR, a likely ligand co-receptor, with Cterminal domain of PpkA can efficiently modulate its signal response. Therefore, it is tempting to speculate that under particular conditions PpkA could interact with other modulatory proteins resulting in altered substrate specificity.

PpkA has been recently shown to be a crucial regulatory element necessary for the recruitment of the newly identified type 6 secretion system and the secretion of Hcp1, VgrG1 and VgrG4 and Tse1-3 proteins $[15,16,20]$. The pleiotropic effect of the $p p p A-p p k A$ deletion on the cellular functions and physiology of $P$. aeruginosa suggests that this post-translational regulation of protein secretion is very likely only one of the molecular mechanisms that are under PpkA-PppA control. This hypothesis was proven by global analyses of transcriptomes of the wild-type and mutant strains under stressfree and oxidative stress conditions.

We hypothesise that deregulation of the response to environmental conditions such as oxidative stress and interference with RpoS/QS regulons as well as genes of the phosphate acquisition system would lead to decreased survival of the mutant within the host and attenuated virulence. These features were proven by the macrophage survival assay and in the plant model of infection. We suggest that the PppA-PpkA regulation pair, besides its role in T6SS, may also exert a direct or indirect effect on the regulation of stress responses likely through RpoS/QS regulons, thus influencing the virulence of $P$. aeruginosa. Therefore, it seems that PpkA targets some other substrate proteins outside H1-T6SS cluster and affects a broad range of cellular processes. It has been shown that other factors can contribute to in vivo substrate specificity of the individual kinases [83]. These factors are likely to include coordinated expression and colocalization of kinase and substrate, and 
protein-protein interactions. The identification of substrates and interacting factors that are involved in PpkA specificity will provide the grounds for further investigation.

\section{Additional material}

Additional file 1: Table S1. Oligonucleotides used in this study. Additional file 2: Figure S1. Characteristics of $P$. aeruginosa PAO1 wild-type and $\triangle p p p A-p p k A$ strains. (A) Growth curves in King's A and King's B medium. (B) Growth curves in Casamino Acid medium (CAA). This figure presents growth curves of Pseudomonas aeruginosa PAO1 wild-type and $\triangle p p p A-p p k A$ strains in King's media containing glycerol and CAA medium.

Additional file 3: Figure S2. Phenotypic analysis of complemented strain $\Delta::$ tn7TLACpak. (A) Growth curve in minimal M9 medium. (B) Survival upon exposure to oxidative stress. (C) Survival upon exposure to osmotic stress. (D) Production of pyoverdine. (E) Plant (lettuce) infection assay with the $P$. aeruginosa PA01::tn7TLAC (1), $\Delta:: \operatorname{tn} 7 T L A C(2)$, and $\Delta:: t n 7 T L A C p a k(3)$ strains. This figure presents phenotypic features of the complemented strain $\triangle:$ :tn7TLACpak in comparison with wild-type strain PAO1::tn7TLAC and mutant $\triangle .:$ tn7TLAC strain.

\section{Acknowledgements}

We are grateful to Thilo Köhler (University of Geneva) for the gift of $P$. aeruginosa PAO1 wild type strain and Herbert P. Schweizer (Colorado State University) for the gift of plasmids pEX18Ap, pFLP2, pPS858, pUC18-miniTn7T-LAC and pTNS2. This work was supported by the Czech Science Foundation (grant no. 204/08/0783 to PB), the Grant Agency of the Charles University in Prague (Project no. 161/2006/B-BIO/PrF to JG) and by Institutional Research Concept grant AV0Z50200510.

\section{Author details}

${ }^{1}$ Cell and Molecular Microbiology Division, Institute of Microbiology of the ASCR, v.v.i., Academy of Sciences of the Czech Republic, Vídeňská 1083, 142 20 Prague 4, Czech Republic. 'Laboratory of Molecular Genetics, National Institute of Child Health and Human Development, National Institutes of Health, Bethesda, MD 20892, USA.

\section{Authors' contributions}

PB and JG designed the study. JG performed experiments, analysed data and drafted the manuscript. AU assisted with bioinformatic analysis and interpreting analysis results. $\mathrm{KH}$ built initial constructs and assisted in the construction of mutant strain. PB supervised the project and edited the manuscript. All authors discussed the results and implications and commented on the manuscript at all stages. All authors read and approved the final manuscript.

Received: 21 February 2011 Accepted: 31 August 2011

Published: 31 August 2011

\section{References}

1. Lyczak JB, Cannon CL, Pier GB: Establishment of Pseudomonas aeruginosa infection: lessons from a versatile opportunist. Microbes Infect 2000, 2:1051-60.

2. Suh SJ, Silo-Suh L, Woods DE, Hassett DJ, West SE, Ohman DE: Effect of rpoS mutation on the stress response and expression of virulence factors in Pseudomonas aeruginosa. J Bacteriol 1999, 181:3890-7.

3. Lambert PA: Mechanisms of antibiotic resistance in Pseudomonas aeruginosa. J R Soc Med 2002, 95(Suppl 41):22-6.

4. Stewart PS: Mechanisms of antibiotic resistance in bacterial biofilms. Int $J$ Med Microbiol 2002, 292:107-13.

5. Nadvornik R, Vomastek T, Janecek J, Technikova Z, Branny P: Pkg2, a novel transmembrane protein Ser/Thr kinase of Streptomyces granaticolor. J Bacteriol 1999, 181:15-23.
6. Umeyama T, Horinouchi S: Autophosphorylation of a bacterial serine/ threonine kinase, AfsK, is inhibited by KbpA, an AfsK-binding protein. $J$ Bacteriol 2001, 183:5506-12.

7. Thakur M, Chakraborti PK: GTPase activity of mycobacterial FtsZ is impaired due to its transphosphorylation by the eukaryotic-type Ser/Thr kinase, PknA. J Biol Chem 2006, 281:40107-13.

8. Ueda K, Umeyama T, Beppu T, Horinouchi S: The aerial myceliumdefective phenotype of Streptomyces griseus resulting from A-factor deficiency is suppressed by a Ser/Thr kinase of S. coelicolor A3(2). Gene 1996, 169:91-5

9. Zheng J, He C, Singh VK, Martin NL, Jia Z: Crystal structure of a novel prokaryotic Ser/Thr kinase and its implication in the Cpx stress response pathway. Mol Microbiol 2007, 63:1360-71.

10. Hussain $H$, Branny $P$, Allan E: A eukaryotic-type serine/threonine protein kinase is required for biofilm formation, genetic competence, and acid resistance in Streptococcus mutans. J Bacteriol 2006, 188:1628-32.

11. Ohlsen K, Donat S: The impact of serine/threonine phosphorylation in Staphylococcus aureus. Int J Med Microbiol 2010, 300:137-141.

12. Walburger A, Koul A, Ferrari G, Nguyen L, Prescianotto-Baschong C, Huygen K, Klebl B, Thompson C, Bacher G, Pieters J: Protein kinase G from pathogenic mycobacteria promotes survival within macrophages. Science 2004, 304:1800-4.

13. Dukuzumuremyi JM, Rosqvist $\mathrm{R}$, Hallberg $\mathrm{B}$, Akerstrom $\mathrm{B}$, Wolf-Watz $\mathrm{H}$, Schesser K: The Yersinia protein kinase $A$ is a host factor inducible RhoA/ Rac-binding virulence factor. J Biol Chem 2000, 275:35281-90.

14. Wiley DJ, Nordfeldth R, Rosenzweig J, DaFonseca CJ, Gustin R, Wolf-Watz H, Schesser $\mathrm{K}$ : The Ser/Thr kinase activity of the Yersinia protein kinase A (YpkA) is necessary for full virulence in the mouse, mollifying phagocytes, and disrupting the eukaryotic cytoskeleton. Microb Pathog 2006, 40:234-243.

15. Hood RD, Singh P, Hsu F, Guvener T, Carl MA, Trinidad RR, Silverman JM, Ohlson BB, Hicks KG, Plemel RL, Li M, Schwarz S, Wang WY, Merz AJ, Goodlett DR, Mougous JD: A type VI secretion system of Pseudomonas aeruginosa targets a toxin to bacteria. Cell Host Microbe 2010, 7:25-37.

16. Mougous JD, Gifford CA, Ramsdell TL, Mekalanos JJ: Threonine phosphorylation post-translationally regulates protein secretion in Pseudomonas aeruginosa. Nat Cell Biol 2007, 9:797-803.

17. Wang J, Li C, Yang H, Mushegian A, Jin S: A novel serine/threonine protein kinase homologue of Pseudomonas aeruginosa is specifically inducible within the host infection site and is required for full virulence in neutropenic mice. J Bacteriol 1998, 180:6764-8.

18. Motley ST, Lory S: Functional characterization of a serine/threonine protein kinase of Pseudomonas aeruginosa. Infect Immun 1999, 67:5386-5394.

19. Mougous JD, Cuff ME, Raunser S, Shen A, Zhou M, Gifford CA Goodman AL, Joachimiak G, Ordonez CL, Lory S, Walz T, Joachimiak A Mekalanos JJ: A virulence locus of Pseudomonas aeruginosa encodes a protein secretion apparatus. Science 2006, 312:1526-30.

20. Hachani A, Lossi NS, Hamilton A, Jones C, Bleves S, Albesa-Jové D, Filloux A: Type VI secretion system in Pseudomonas Aeruginosa: secretion and multimerization of VgrG proteins. J Biol Chem 2011

21. Hsu F, Schwarz S, Mougous JD: TagR promotes PpkA-catalysed type VI secretion activation in Pseudomonas aeruginosa. Mol Microbiol 2009, 72:1111-1125.

22. Branny P, Pearson JP, Pesci EC, Kohler T, Iglewski BH, Van Delden C: Inhibition of quorum sensing by a Pseudomonas aeruginosa $\mathrm{dks} A$ homologue. J Bacteriol 2001, 183:1531-9.

23. Merck: Microbiology manual. Merck Darmstadt, Germany 1996.

24. Kohler T, Curty LK, Barja F, Van Delden C, Pechere JC: Swarming of Pseudomonas aeruginosa is dependent on cell-to-cell signaling and requires flagella and pili. J Bacteriol 2000, 182:5990-6.

25. Vasseur P, Vallet-Gely I, Soscia C, Genin S, Filloux A: The pel genes of the Pseudomonas aeruginosa PAK strain are involved at early and late stages of biofilm formation. Microbiology 2005, 151:985-97.

26. Hoang T, Karkhoff-Schweizer RR, Kutchma AJ, Schweizer HP: A broad-hostrange Flp-FRT recombination system for site-specific excision of chromosomally-located DNA sequences: application for isolation of unmarked Pseudomonas aeruginosa mutants. Gene 1998, 212:77-86.

27. Choi KH, Schweizer HP: mini-Tn7 insertion in bacteria with single attTn7 sites: example Pseudomonas aeruginosa. Nat Protoc 2006, 1:153-161. 
28. Whitchurch CB, Beatson SA, Comolli JC, Jakobsen T, Sargent $J$, Bertrand JJ, West J, Klausen M, Waite LL, Kang PJ, Tolker-Nielsen T, Mattick JS, Engel JN: Pseudomonas aeruginosa fimL regulates multiple virulence functions by intersecting with Vfr-modulated pathways. Mol Microbiol 2005, 55:1357-1378

29. Schweizer HP, Choi KH: Pseudomonas aeruginosa aerobic fatty acid desaturase DesB is important for virulence factor production. Arch Microbiol 2011, 193:227-234.

30. Essar DW, Eberly L, Hadero A, Crawford IP: Identification and characterization of genes for a second anthranilate synthase in Pseudomonas aeruginosa: interchangeability of the two anthranilate synthases and evolutionary implications. J Bacterio/ 1990, 172:884-900.

31. Rust L, Messing CR, Iglewski BH: Elastase assays. Methods Enzymol 1994, 235:554-562

32. Visca P, Serino L, Orsi N: Isolation and characterization of Pseudomonas aeruginosa mutants blocked in the synthesis of pyoverdin. J Bacteriol 1992, 174:5727-5731.

33. May TB, Chakrabarty AM: Isolation and assay of Pseudomonas aeruginosa alginate. Methods Enzymol 1994, 235:295-304.

34. Szybalski W, Bryson V: Genetic studies on microbial cross resistance to toxic agents. I. Cross resistance of Escherichia coli to fifteen antibiotics. J Bacteriol 1952, 64:489-99.

35. Filipe SR, Tomasz A: Inhibition of the expression of penicillin resistance in Streptococcus pneumoniae by inactivation of cell wall muropeptide branching genes. Proc Natl Acad Sci USA 2000, 97:4891-6.

36. $\mathrm{Yu} \mathrm{H}$, Boucher JC, Hibler NS, Deretic V: Virulence properties of Pseudomonas aeruginosa lacking the extreme-stress sigma factor AlgU (sigmaE). Infect Immun 1996, 64:2774-81.

37. Rahme LG, Tan MW, Le L, Wong SM, Tompkins RG, Calderwood SB, Ausubel FM: Use of model plant hosts to identify Pseudomonas aeruginosa virulence factors. Proc Natl Acad Sci USA 1997, 94:13245-50.

38. R DEVELOPMENT CORE TEAM: R: A Language and Environment for Statistical Computing. 2009 [http://www.r-project.org].

39. Irizarry RA, Bolstad BM, Collin F, Cope LM, Hobbs B, Speed TP: Summaries of Affymetrix GeneChip probe level data. Nucleic Acids Res 2003, 31:e15.

40. Smyth GK: Linear models and empirical bayes methods for assessing differential expression in microarray experiments. Stat Appl Genet Mol Biol 2004, 3:Article3.

41. Gentleman RC, Carey VJ, Bates DM, Bolstad B, Dettling M, Dudoit S, Ellis B, Gautier L, Ge Y, Gentry J, Hornik K, Hothorn T, Huber W, lacus S, Irizarry R, Leisch F, Li C, Maechler M, Rossini AJ, Sawitzki G, Smith C, Smyth G, Tierney L, Yang JY, Zhang J: Bioconductor: open software development for computational biology and bioinformatics. Genome Biol 2004, 5:R80.

42. Benjamini Y, Hochberg Y: Controlling the False Discovery Rate: a Practical and powerful Approach to Multiple Testing. Journal of the Royal Statistical Society 1995, 57:289-300.

43. Savli H, Karadenizli A, Kolayli F, Gundes S, Ozbek U, Vahaboglu H: Expression stability of six housekeeping genes: A proposal for resistance gene quantification studies of Pseudomonas aeruginosa by real-time quantitative RT-PCR. J Med Microbiol 2003, 52:403-408.

44. Livak KJ, Schmittgen TD: Analysis of relative gene expression data using real-time quantitative $P C R$ and the 2(-Delta Delta $C(T)$ ) Method. Methods 2001, 25:402-408.

45. Pfaffl MW: A new mathematical model for relative quantification in realtime RT-PCR. Nucleic Acids Res 2001, 29:e45.

46. Berry A, DeVault JD, Chakrabarty AM: High osmolarity is a signal for enhanced $\operatorname{alg} D$ transcription in mucoid and nonmucoid Pseudomonas aeruginosa strains. J Bacterio/ 1989, 171:2312-2317.

47. Kohler T, Van Delden C, Curty LK, Hamzehpour MM, Pechere JC: Overexpression of the MexEF-OprN multidrug efflux system affects cellto-cell signaling in Pseudomonas aeruginosa. J Bacteriol 2001, 183:5213-22.

48. Rahme LG, Ausubel FM, Cao H, Drenkard E, Goumnerov BC, Lau GW, Mahajan-Miklos S, Plotnikova J, Tan MW, Tsongalis J, Walendziewicz CL, Tompkins RG: Plants and animals share functionally common bacterial virulence factors. Proc Natl Acad Sci USA 2000, 97:8815-21.

49. Chang W, Small DA, Toghrol F, Bentley WE: Microarray analysis of Pseudomonas aeruginosa reveals induction of pyocin genes in response to hydrogen peroxide. BMC Genomics 2005, 6:115.

50. Palma M, DeLuca D, Worgall S, Quadri LE: Transcriptome analysis of the response of Pseudomonas aeruginosa to hydrogen peroxide. J Bacteriol 2004, 186:248-252.
51. Salunkhe P, Topfer T, Buer J, Tummler B: Genome-wide transcriptional profiling of the steady-state response of Pseudomonas aeruginosa to hydrogen peroxide. J Bacteriol 2005, 187:2565-72.

52. Schuster M, Hawkins AC, Harwood CS, Greenberg EP: The Pseudomonas aeruginosa RpoS regulon and its relationship to quorum sensing. $\mathrm{Mo}$ Microbiol 2004, 51:973-85.

53. Schuster M, Lostroh CP, Ogi T, Greenberg EP: Identification, timing, and signal specificity of Pseudomonas aeruginosa quorum-controlled genes: a transcriptome analysis. J Bacteriol 2003, 185:2066-2079.

54. Wagner VE, Bushnell D, Passador L, Brooks Al, Iglewski BH: Microarray analysis of Pseudomonas aeruginosa quorum-sensing regulons: effects of growth phase and environment. J Bacterio/ 2003, 185:2080-2095.

55. Bredenbruch F, Geffers R, Nimtz M, Buer J, Haussler S: The Pseudomonas aeruginosa quinolone signal (PQS) has an iron-chelating activity. Environ Microbiol 2006, 8:1318-1329.

56. Deziel E, Gopalan S, Tampakaki AP, Lepine F, Padfield KE, Saucier M, Xiao G, Rahme LG: The contribution of MvfR to Pseudomonas aeruginosa pathogenesis and quorum sensing circuitry regulation: multiple quorum sensing-regulated genes are modulated without affecting lasRl, rhIRI or the production of $\mathrm{N}$-acyl-L-homoserine lactones. Mol Microbiol 2005, 55:998-1014.

57. Ma JF, Hager PW, Howell ML, Phibbs PV, Hassett DJ: Cloning and characterization of the Pseudomonas aeruginosa zwf gene encoding glucose-6-phosphate dehydrogenase, an enzyme important in resistance to methyl viologen (paraquat). J Bacteriol 1998, 180:1741-1749.

58. Gohlke U, Warne A, Saraste M: Projection structure of the cytochrome bo ubiquinol oxidase from Escherichia coli at 6 A resolution. EMBO J 1997, 16:1181-1188.

59. Keyer K, Imlay JA: Inactivation of dehydratase [4Fe-4S] clusters and disruption of iron homeostasis upon cell exposure to peroxynitrite. J Biol Chem 1997, 272:27652-27659.

60. Hummerjohann J, Kuttel E, Quadroni M, Ragaller J, Leisinger T, Kertesz MA: Regulation of the sulfate starvation response in Pseudomonas aeruginosa: role of cysteine biosynthetic intermediates. Microbiology 1998, 144(Pt 5):1375-1386.

61. Kertesz MA, Schmidt-Larbig $K$, Wuest $T$ : $A$ novel reduced flavin mononucleotide-dependent methanesulfonate sulfonatase encoded by the sulfur-regulated msu operon of Pseudomonas aeruginosa. J Bacteriol 1999, 181:1464-1473.

62. Hogardt M, Roeder M, Schreff AM, Eberl L, Heesemann J: Expression of Pseudomonas aeruginosa exoS is controlled by quorum sensing and RpoS. Microbiology 2004, 150:843-851.

63. Bernard CS, Bordi C, Termine E, Filloux A, de BS: Organization and PprBdependent control of the Pseudomonas aeruginosa tad Locus, involved in Flp pilus biology. J Bacteriol 2009, 191:1961-1973.

64. Aspedon A, Palmer K, Whiteley M: Microarray analysis of the osmotic stress response in Pseudomonas aeruginosa. J Bacteriol 2006, 188:2721-2725.

65. Hassett DJ, Howell ML, Ochsner UA, Vasil ML, Johnson Z, Dean GE: An operon containing fum $C$ and sodA encoding fumarase $C$ and manganese superoxide dismutase is controlled by the ferric uptake regulator in Pseudomonas aeruginosa: fur mutants produce elevated alginate levels. J Bacteriol 1997, 179:1452-1459.

66. Small DA, Chang W, Toghrol F, Bentley WE: Comparative global transcription analysis of sodium hypochlorite, peracetic acid, and hydrogen peroxide on Pseudomonas aeruginosa. Appl Microbiol Biotechnol 2007, 76:1093-1105.

67. Michel-Briand Y, Baysse C: The pyocins of Pseudomonas aeruginosa. Biochimie 2002, 84:499-510.

68. Ochsner UA, Wilderman PJ, Vasil AI, Vasil ML: GeneChip expression analysis of the iron starvation response in Pseudomonas aeruginosa: identification of novel pyoverdine biosynthesis genes. Mol Microbiol 2002, 45:1277-1287.

69. Zheng P, Sun J, Geffers R, Zeng AP: Functional characterization of the gene PA2384 in large-scale gene regulation in response to iron starvation in Pseudomonas aeruginosa. J Biotechnol 2007, 132:342-352.

70. Cotter PA, Melville SB, Albrecht JA, Gunsalus RP: Aerobic regulation of cytochrome d oxidase (cydAB) operon expression in Escherichia coli: roles of Fnr and ArcA in repression and activation. Mol Microbiol 1997 25:605-615. 
71. Chugani S, Greenberg EP: The influence of human respiratory epithelia on Pseudomonas aeruginosa gene expression. Microb Pathog 2007, 42:29-35.

72. Empadinhas $\mathrm{N}$, da Costa MS: Osmoadaptation mechanisms in prokaryotes: distribution of compatible solutes. Int Microbiol 2008, 11:151-161.

73. Freeman $\mathrm{BC}$, Chen $\mathrm{C}$, Beattie GA: Identification of the trehalose biosynthetic loci of Pseudomonas syringae and their contribution to fitness in the phyllosphere. Environ Microbiol 2010.

74. Strom AR, Kaasen I: Trehalose metabolism in Escherichia coli: stress protection and stress regulation of gene expression. Mol Microbiol 1993 8:205-210.

75. Monds RD, Silby MW, Mahanty HK: Expression of the Pho regulon negatively regulates biofilm formation by Pseudomonas aureofaciens PA147-2. Mol Microbiol 2001, 42:415-426.

76. Jensen V, Lons D, Zaoui C, Bredenbruch F, Meissner A, Dieterich G, Munch R, Haussler S: RhIR expression in Pseudomonas aeruginosa is modulated by the Pseudomonas quinolone signal via PhoB-dependent and -independent pathways. J Bacteriol 2006, 188:8601-8606.

77. Kang Y, Lunin W, Skarina T, Savchenko A, Schurr MJ, Hoang TT: The longchain fatty acid sensor, PsrA, modulates the expression of rpoS and the type III secretion exsCEBA operon in Pseudomonas aeruginosa. Mol Microbiol 2009, 73:120-136.

78. MacEachran DP, Stanton BA, O'Toole GA: Cif is negatively regulated by the TetR family repressor CifR. Infect Immun 2008, 76:3197-3206.

79. Frisk A, Schurr JR, Wang G, Bertucci DC, Marrero L, Hwang SH, Hassett DJ, Schurr MJ: Transcriptome analysis of Pseudomonas aeruginosa after interaction with human airway epithelial cells. Infect Immun 2004, 72:5433-5438.

80. Zaborina O, Holbrook C, Chen Y, Long J, Zaborin A, Morozova I, Fernandez H, Wang Y, Turner JR, Alverdy JC: Structure-function aspects of PstS in multi-drug-resistant Pseudomonas aeruginosa. PLoS Pathog 2008, 4:e43

81. Greenstein AE, Echols N, Lombana TN, King DS, Alber T: Allosteric activation by dimerization of the PknD receptor Ser/Thr protein kinase from Mycobacterium tuberculosis. J Biol Chem 2007, 282:11427-35.

82. Lombana TN, Echols N, Good MC, Thomsen ND, Ng HL, Greenstein AE, Falick AM, King DS, Alber T: Allosteric Activation Mechanism of the Mycobacterium tuberculosis Receptor Ser/Thr Protein Kinase, PknB. Structure 2010, 18:1667-1677.

83. Prisic S, Dankwa S, Schwartz D, Chou MF, Locasale JW, Kang CM, Bemis G, Church GM, Steen H, Husson RN: Extensive phosphorylation with overlapping specificity by Mycobacterium tuberculosis serine/threonine protein kinases. Proc Natl Acad Sci USA 2010, 107:7521-7526.

doi:10.1186/1471-2164-12-437

Cite this article as: Goldová et al:: A eukaryotic-type signalling system of Pseudomonas aeruginosa contributes to oxidative stress resistance, intracellular survival and virulence. BMC Genomics 2011 12:437.

\section{Submit your next manuscript to BioMed Central and take full advantage of:}

- Convenient online submission

- Thorough peer review

- No space constraints or color figure charges

- Immediate publication on acceptance

- Inclusion in PubMed, CAS, Scopus and Google Scholar

- Research which is freely available for redistribution

Submit your manuscript at www.biomedcentral com/submit
C Biomed Central 